Mehmet Akif Ersoy Üniversitesi Fen Bilimleri Enstitüsü Dergisi 10(1): $34-50$ (2019)

The Journal of Graduate School of Natural and Applied Sciences of Mehmet Akif Ersoy University 10(1): $34-50$ (2019)

Araştırma Makalesi / Research Paper

\title{
İki Ankrajı Çelik Palplanş Sisteminin Optimum Tasarımı
}

\author{
Mehmet Fatih YAZICI ${ }^{1}{ }^{*}$, Sıddıka Nilay KESKIN ${ }^{D} 1$ \\ ${ }^{1}$ Süleyman Demirel Üniversitesi, Mühendislik Fakültesi, Isparta \\ Geliş Tarihi (Received): 06.03.2019, Kabul Tarihi (Accepted): 19.04.2019 \\ $\square$ Sorumlu Yazar (Corresponding author*): mehmetyazici@sdu.edu.tr \\ (C) +902462111197 且 +902462370859
}

\section{ÖZ}

Günümüzde derin kazı problemleriyle sıkça karşılaşılmaktadır. Derin kazı gerektiren inşaat işlerinde kazı alanı civarındaki mevcut yapıların zarar görmesini engellemek amacıyla bir iksa sisteminin kullanılması gerekmektedir. Bu amaç için kullanılan iksa sistemlerinden biri olan ankrajlı çelik palplanş duvarlar, diğer duvar türlerine nazaran yüksek çakma gerilmelerine olan direncinden, nispeten hafif olmalarından, uzun servis ömrüne sahip olmalarından ve de tekrar tekrar kullanılabilme özelliğinden dolayı yaygın bir şekilde tercih edilmektedirler. Gerekli iksa yapısını tasarlayacak bir geoteknik tasarımcının görevlerinden biri güvenli ve ekonomik bir tasarım yapmaktır. Literatürde ankrajı palplanş sistemlerinin tasarımı ile ilgili yeterince çalışma olmasına karşın optimizasyon çalışmaları yetersizdir. Bu nedenle bu çalışmada, orta sıkı kuru kum zemin içerisine çakılan palplanş sisteminde ankrajların yatay ve düşey aralıkları ile ankraj açıları değiştirilerek palplanş sisteminin maliyeti üzerine bir optimizasyon hesabı yapılmıştır. Sonuç olarak 11296 adet farklı geometri durumu incelenerek her biri için maliyet fonksiyonları oluşturulmuş ve en düşük maliyetlerin genellikle ankraj açısının $15^{\circ}$ ve ankrajlar arası yatay mesafenin $3 \mathrm{~m}$ olduğu durumda meydana geldiği gözlemlenmiştir.

Anahtar Kelimeler: Ankrajı palplanş duvarlar, optimizasyon, iksa sistemleri, derin kazı

\section{Optimum Design of Two Anchored Steel Sheet Pile System}

\begin{abstract}
Deep excavation problems are frequently encountered today. In case of construction works requiring deep excavation, a retaining system should be used to prevent damage to existing buildings around the excavation area. Steel sheet pile walls which are one of the retaining systems used for this purpose, are relatively preferred due to their resistance to high driving stresses, lightweight, long service life and the ability to use them repeatedly compared to other types of wall. One of the tasks of a geotechnical engineering who will design the required retaining structure is to create a safe and economical design. Although there are enough studies in the literature about the design of anchored pile systems, optimization studies are insufficient. For this reason, in this study, an optimization calculation has been made on cost of sheet pile system by changing lateral and vertical spacing of anchors and angles of anchor in sheet pile system which is driven into medium dense sand soil. As a result, 11296 different geometry conditions have been examined and cost functions have been established for each. Finally it has been observed that the lowest costs usually occur when the angle of anchor is $15^{\circ}$ and horizontal distance between the anchors is $3 \mathrm{~m}$.
\end{abstract}

Keywords: Anchored sheet pile walls, optimization, retaining structures, deep excavation 


\section{Giriş}

Günümüzde yapımı hızla artan yüksek yapıların ve otoparkların inşaatlarında ve de gelişen teknolojinin beraberinde getirdiği çok bodrumlu alışveriş merkezleri, metro istasyonları ve altgeçitler gibi yapıların inşaatlarında derin kazı problemleriyle sıkça karşılaşımaktadır. $\mathrm{Bu}$ sebeple derin kazı gerektiren inşaat işlerinde kazı alanına yakın mevcut bina, yol, elektrik, su vb. sistemlerin zarar görmesini engellemek ve de kazı alanı içerisinde güvenli bir çalışma ortamı elde edilebilmek amacıyla kazı yan yüzeylerinin stabilizasyonu için iksa sistemi kullanımı gerekmektedir. Bu amaç için; ağırlık duvarları, diyafram duvarlar, donatılı zemin duvarlar, istinat duvarları, kazıklı perde duvarlar, palplanş duvarlar vb. kullanılmaktadır. Diğer duvar türlerine nazaran yüksek çakma gerilmelerine olan direncinden, nispeten hafif olmalarından, uzun servis ömrüne sahip olmalarından ve de tekrar tekrar kullanılabilme özelliğinden dolayı çelik palplanşlar yaygın bir şekilde tercih edilmektedirler.

Genel olarak palplanş duvarlar; rıhtım yapıları, koferdamlar, barajlar altında sızma perdesi, erozyon koruması, kazı destek sistemi ve taşkın duvarlar olarak, ayrıca zemin şevlerinin stabilizasyonunda kullanılmaktadır (Amer, 2013).

Palplanş duvarlar konsol olarak veya ankrajlı olarak inşa edilebilirler. Genellikle 3-5 m'den daha az duvar yükseklikleri için konsol palplanş duvar kullanılırken, daha yüksek duvarlar için veya yatay duvar deformasyonlarının sınırlandırılmasının zorunlu olduğu durumlarda ankrajlı palplanş duvarlar tercih edilmektedir (NCHRP, 2008).

İksa sistemleri için literatürde yapılan çalışmalar aşağıda verilmiştir.

Lopez ve ark. (2017), orta sıkı bir zemini destekleyen ve nispeten sığ kazılar içerisindeki konsol veya ankrajı palplanş duvarlar için geliştirilen FHWA (1999) yönetmeliğini kullanarak sıkı çakıllı zemin içerisindeki derin kazıda inşa edilen palplanş duvar üzerinde statik analizlerini gerçekleştirmiştir. Ayrıca araştırmacı, statik analizlerde kullandığı verileri dikkate alarak palplanş sistemini PLAXIS 2D programıla modellemiş ve elde ettiği sonuçları, elle yapılan hesaplama sonuçları ile karşıllaştırmıştır. Sonuç olarak araştırmacı, 2 boyutlu sonlu elemanlar yönteminden hesapladığı kazığa gelen statik toprak basınçlarının ve ankrajlara gelen çekme kuvvetlerinin FHWA (1999) tarafından önerilen toprak basıncı zarfları kullanılarak elde edilenler ile mükemmel bir uyum içerisinde olduğunu ifade etmiştir.

Erdem ve ark. (2015), 30*20 $\mathrm{m}^{2}$ 'lik bir alan içerisindeki gevşek, orta sıkı ve sıkı kum zeminlerde yapılacak bir derin kazı içerisinde; $60 \mathrm{~cm}$ ve $80 \mathrm{~cm}$ genişliğinde diyafram duvar, $30 \mathrm{~cm}, 65 \mathrm{~cm}$ ve $80 \mathrm{~cm}$ çapında kazıklı perde ve $6 \mathrm{~mm}$ ile $10 \mathrm{~mm}$ kalınlığındaki palplanş duvarların her birini PLAXIS V8 ile ayrı ayrı inceleyerek yaklaşık bir maliyet hesabı oluşturmuştur. Sonuç olarak araştırmacı, tüm zemin sınıfları için en düşük yatay deplasman değerini $80 \mathrm{~cm}$ çapa sahip diyafram duvarın verdiğini ve 30 $\mathrm{cm}$ çapa sahip kazık dikkate alınmazsa en büyük yatay deplasman değerini palplanşların verdiğini ileri sürmüştür. Ayrıca araştırmacı, maliyet analizleri sonucunda 80 $\mathrm{cm}$ çapa sahip kazıklı perdenin en düşük maliyete sahip olduğunu iddia etmiştir.

Das ve Das (2015), basit bir optimizasyon aracı olan Microsoft Excel Solver programını kullanarak kile gömülü hem konsol hem de ankrajlı palplanş duvarların optimum tasarımını incelemişlerdir. Ayrıca optimum tasarım üzerine zemin özelliklerinin, penetrasyon derinliğinin ve yer altı su tablasının değişiminin etkisini de tartışmışlardır. Analizler sonucunda araştırmacılar, efektif içsel sürtünme açısı değerinin artması ile ankrajı palplanşın optimum gömme derinliğinin ve ankraj kuvvetinin azaldığını ve de ankrajın duvar üst yüzeyine olan mesafesinin artması ile optimum gömme derinliğinin azaldığını, ankraj kuvvetinin arttığını gözlemlemişlerdir. Ayrıca içsel sürtünme açısı arttıkça konsol palplanşın optimum gömme derinliğinin azaldığını görmüşlerdir. Öte yandan araştırmacılar, su tablası seviyesinin alçalması ile konsol palplanşın optimum gömme derinliğinde bir artış meydana geldiğini ve hatta optimum gömme derinliğindeki bu artışın, özellikle kazı derinliğinin artması ve su tablasının zemin üst yüzüne olan mesafesinin kazı derinliğine oranının 0.6 olması durumunda oldukça önemli olduğunu gözlemlemişlerdir.

Arslan ve Öztoprak (2005), MS EXCEL ortamında hazırladıkları BAnk05 adlı programı kullanarak, tamamen kum zeminden oluşan bir profilde kazı derinliğini 4 metreden 20 metreye, tamamen kil zeminden oluşan bir profilde de kazı derinliğini 4 metreden 16 metreye kadar 2 'şer metre aralıklarla değiştirerek, hem konsol fore kazık hem de tek ve çok sıra ankrajlı iksa sistemleri için analizler yapmışlar ve işçilik ile kullanılan malzeme maliyetlerinin toplamını her durum için kıyaslamışlardır. Sonuçta, killi zeminde yaklaşık 9 metrede hem konsol hem de çok sıra ankrajı iki iksa sistemin maliyetlerinin yakın olduğunu, 4-9 metre arası konsol fore kazığın, 9-20 metre arası ise ankrajlı iksanın daha ekonomik olduğunu gözlemlemişlerdir. Öte yandan kumlu zeminde 8 metrede maliyetlerin eşit, daha küçük derinliklerde konsol fore kazığın ekonomik, daha büyük derinliklerde ise ankrajlı sistemin daha ekonomik olduğu sonucunu elde etmişlerdir. 
Bhanuchitra ve Prusty (2010), iksa sisteminin ekonomik tasarımı için PLAXIS yazılımını kullanarak zemin davranışını elasto-plastik Mohr-Coulomb modeli ile ve zemin tabakalarını düzlemsel şekil değiştirme koşullarında 15 düğümlü üçgen elemanlar ile temsil ederek bir çalışma yapmışlardır. Araştırmacılar elle hesaplarda toprak basıncının uygun bir şekilde seçilmesi ile iksa sisteminin maliyetinin optimize edilebileceğini savunmuşlardır. $K_{A}$ aktif toprak basıncı katsayısının iksa sisteminin maliyeti üzerine büyük bir etkiye sahip olduğunu ve dikkatli bir şekilde değerlendirilmesi gerektiğini önermişler ve ayrıca bir sonlu eleman yazılımı kullanmanın zemin yapı etkileşimine dayalı olarak gerçek $\mathrm{K}_{\mathrm{A}}$ değerlerini belirlemeye yardım ettiğini ileri sürmüşlerdir. Buna ilave olarak da iksa sisteminde kullanılan kazık elemanının çapı arttıkça $\mathrm{K}_{\mathrm{A}}$ 'nın ve sonuç olarak sisteme etkiyen toprak basıncının da artacağını gözlemlemişlerdir.

Mahdi ve Ebid (2015), kuru granüler bir zeminde konsol palplanş duvarın optimum penetrasyon derinliğini belirlemek için alternatif bir formül ortaya çıkartmak ve iksa sisteminin maliyeti üzerine optimum derinliği kullanmanın etkisini araştırmak için istatistiksel çalışmalar yapmışlar ve elde ettikleri sonuçları geleneksel yöntemle karşılaştırmışlardır. Sonuç olarak araştırmacılar, stabilite için kabul edilebilir güvenlik sınırları içerisinde kalabilmek amacıyla, geleneksel yöntemle hesaplanan penetrasyon derinliğinin \%20 ile \% 40 arttırılmasının doğru olduğunu ve hatta çok gevşek zeminler için $\% 20$, çok sıkı zeminler için ise \%40 değerinin kullanılması gerektiğini ifade etmişlerdir. Araştırmanın diğer bir sonucu olarak da maksimum penetrasyon derinliği yerine optimum penetrasyon derinliğinin kullanılmasının, zeminin içsel sürtünme açısı değerine bağlı olarak, konsol palplanş sisteminin maliyetinde doğrudan $\% 5$ ile $\% 10$ kadarlık bir tasarruf sağladığını belirtmişlerdir.

Bir diğer çalışmada ise kum zeminde kazı sonrası stabiliteyi sağlamak için inşa edilen ankrajlı palplanş duvarının PLAXIS 2D ile analizi yapılmıştır. Analizler sırasında ankraj sayısı, ankraj açısı, ankraj boyu, palplanş boyu, yer altı su seviyesi ve palplanş arkasında tutulan zemindeki yayılı yük miktarı gibi değişkenlerin iksa sisteminin stabilitesine etkisi araştırılmıştır. Sonuçta, ankraj sayısı arttıkça palplanşın yanal hareketinde azalma olduğu ve optimum ankraj sayısının 3 olduğu belirtilmiştir. Ayrıca belirli bir uzunluktan sonra ankraj boyunun $(5 \mathrm{~m})$ arttırılmasının sistemin stabilitesine etkisinin azaldığı, ankraj açısının azalması ile palplanş yanal hareketinin azaldığı ve optimum ankraj açısının $15^{\circ}$ olduğu görülmüştür. Öte yandan diğer parametreler optimum değerlerinde alındığında palplanş boyunun optimum değerinin $12,5 \mathrm{~m}$ olduğu, tamamen suya doygun ortama göre kuru ortamda palplanş yanal hareketinin 2,2 kat azaldığı sonucu elde edilmiştir. Yayılı yükün artması ile ise palplanş yanal ve düşey hareketinin, eğilme momenti ve kesme kuvvetinin, payandaya gelen kuvvet ve palplanş arkasındaki zeminde meydana gelen oturmanın arttığı gözlemlenmiştir (Örnek ve ark., 2007).

Fenerci (2010), Adapazarı zeminlerinden dört farklı zemini örnek alarak dört farklı palplanş kesit tipi için dört farklı kazı derinliğini, dört farklı ankraj sayısını ve dört farklı tasarım standardını dikkate alarak uzun ve kısa dönem için 512 adet palplanş perdesi hesabı yapmış ve hesaplarında ReWaRD yazııımını kullanmıştır. Sonuç olarak araştırmacı, kısa vadeli çözümler ile uzun süreli çözümler arasında çok fazla farkııık olmadığını, 5 metreden daha büyük kazılarda duvara etkiyen eğilme momentlerinin artmasından dolayı ankraj kullanımının gerekli olduğunu, gerekli minimum duvar yüksekliğinin ankraj kullanımıyla yaklaşık olarak \%40 civarında azaldığını ifade etmiştir.

Bilgin (2012), sonlu elemanlar ve geleneksel tasarım yöntemlerini kullanarak çeşitli zemin koşulları ve duvar yüksekliklerine sahip tek seviye ankrajı palplanş duvar için 12 farklı durumdan elde ettiği yatay toprak basınçlarını, duvara gelen eğilme momentlerini ve ankraj kuvvetlerini karşılaştırmıştır ve ankraj civarındaki gerilme yoğunlaşmasını dikkate alan yatay toprak basıncı katsayılarını araştırmıştır. Sonuçta, geleneksel tasarım yöntemlerindeki gibi aktif ve pasif toprak basınçlarının derinlikle artmadığını, duvar hareketinin ankraj tarafından sınırlandırılması nedeniyle ankraj seviyesinde gerilme yoğunlaşması olduğunu, kazık ucuna yakın yerlerde pasif basınçlarda azalma ve aktif basınçlarda da bir artışın olduğunu gözlemlemiştir. Ayrıca geleneksel tasarım yönteminin sonlu eleman analizine göre duvara gelen eğilme momentlerini yaklaşık olarak $\% 50$ daha fazla bulduğunu, sonlu eleman analizinden elde edilen ankraj kuvvetlerinin geleneksel yöntemden elde edilenlerden yaklaşık olarak \%40 daha fazla olduğunu ileri sürmüştür.

Gerekli iksa yapısını tasarlayacak bir geoteknik tasarımcının görevlerinden biri güvenli ve ekonomik bir tasarım yapmaktır. Literatürde ankrajı palplanş sistemlerinin tasarımı ile ilgili yeterince çalışma olmasına karşın optimizasyon çalışmaları yetersizdir. Bu nedenle bu çalışmada, orta sıkı kuru kum zemin içerisine çakılan palplanş sisteminin maliyeti üzerine bir optimizasyon hesabı yapılmıştır. Varsayımsal olarak seçilen $15 \mathrm{~m}^{*} 12$ m'lik bir kazı alanı içerisinde yapılacak 15 m'lik kazı durumu için geçici olarak inşa edilecek iki ankrajlı çelik palplanş kesitinde; ankraj açıları ile ankraj düşey ve yatay aralıkları değiştirilerek analizler yapılmıştır. Zemin mekaniğinde kullanılan yatay toprak basıncı zarfları, ankraj ile duvarın birleştiği yerde meydana gelen gerilme yoğunlaşmasını dikkate almadığı için duvara etki edecek yatay toprak basınçlarını belirleyebilmek için FHWA (1999) tarafından çok ankrajlı iksa sistemleri için önerilen trapezoid yatay 
toprak basıncı zarfları kullanılmıştır. Analizlerde, bu toprak basınçlarına ilaveten kazı alanının bitişiğinde çalışmalar yapacak iş makineleri ile yığılan malzeme ağırlıklarını dikkate alan $5 \mathrm{kPa}$ 'ık üniform yayılı bir sürşarj yükü de duvara etkitilmiştir. Duvarın geometrisi ile ilgili kısıtlamalar için de yine FHWA (1999) tarafından tavsiye edilen sınır durumlar dikkate alınmıştır. Ayrıca bu çalışma kapsamında palplanşların yeniden kullanılabilme özelliği referans alınarak palplanş sisteminin 2 yıldan daha az süreli bir proje için kullanılacağı varsayılarak analizlere dinamik etkiler dahil edilmemiştir. Sonuç olarak 11296 adet farklı geometri durumu incelenerek her biri için amaç fonksiyonu olan maliyet fonksiyonları oluşturulmuş ve en düşük maliyeti veren kesit bulunmaya çalışıımıştır.

\section{MATERYAL VE YÖNTEM}

Bu çalışmada orta sıkı kuru kum zemin içerisine çakılan 2 ankrajlı çelik palplanş sisteminin maliyeti üzerine bir optimizasyon çalışması yapılmıştır. Varsayımsal olarak seçilen $15 \mathrm{~m}^{*} 12 \mathrm{~m}$ 'lik bir kazı alanı içerisinde yapılacak $15 \mathrm{~m}$ derinliğindeki kazıda geçici olarak imal edilecek çelik palplanş kesitinde; ankraj açılları ile ankraj düşey ve yatay aralıkları değiştirilerek analizler yapılmıştır. Geleneksel zemin mekaniğinde kullanılan Rankine ve Coulomb teorileri, ankrajlı iksa sistemlerinde ankraj civarındaki gerilme yoğunlaşmasını dikkate almadığı için duvara etki edecek yatay toprak basınçlarını belirleyebilmek için FHWA (1999) tarafından çok ankrajlı palplanş sistemler için önerilen, Şekil 1 'de gösterilen yatay toprak basıncı zarfı kullanılmıştır.

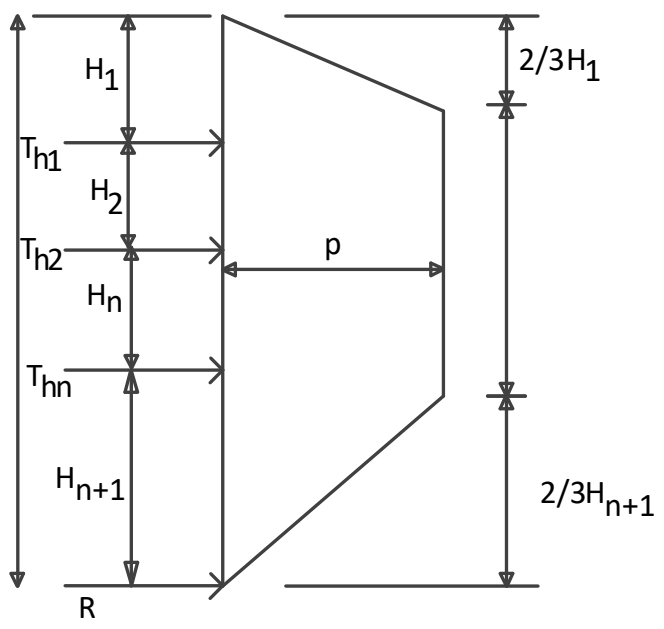

Şekil 1. Kum için tavsiye edilen görünür toprak basıncı diyagramı (FHWA, 1999)

Şekil 1'deki yatay toprak basıncı zarfının maksimum ordinatı olan p değeri Eşitlik (1)'den hesaplanmaktadır.

$$
\mathrm{p}=\frac{\text { toplam yük }}{\mathrm{H}-\frac{\mathrm{H}_{1}}{3}-\frac{\mathrm{H}_{\mathrm{n}+1}}{3}}
$$

Basınç ordinatı p'nin hesabında kullanılacak olan toplam yük değeri, kumlu bir zemin içerisindeki destekli bir kazı durumu için Terzaghi ve Peck (1967) tarafından önerilen toprak basıncı zarfına etki eden toplam yüke eşit olarak alınmış ve bu değer Eşitlik (2)'de gösterilmiştir (FHWA, 1999).

$$
\text { Toplam yük }=0.65 \mathrm{~K}_{\mathrm{a}} * \gamma * \mathrm{H}^{2}
$$

Şekil 1 'de $T_{h 1}, T_{h 2}$ ve $T_{h n}$ her bir ankraja gelen yatay kuvvetleri; $\mathrm{H}_{1}, \mathrm{H}_{2}, \mathrm{H}_{\mathrm{n}}$, ve $\mathrm{H}_{\mathrm{n}+1}$, ankrajların düşey mesafelerini; $\gamma$, zeminin birim hacim ağırlığını; $\mathrm{K}_{\mathrm{a}}$, aktif yatay toprak basıncı katsayısını ve $\mathrm{H}$ kazı derinliğini temsil etmektedir. Analizlerde, bu toprak basınçlarına ilaveten kazı alanının bitişiğinde çalışmalar yapacak iş makineleri ile yığılan malzeme ağırlıklarını dikkate alan $5 \mathrm{kPa}$ 'ık üniform yayılı bir sürşarj yükü de duvara etkitilmiştir. Duvarın geometrisi ile ilgili kısıtlamalar için de yine FHWA (1999) tarafından tavsiye edilen sınır durumlar dikkate alınmıştır. Seçilen kazı derinlikleri 25 m'den daha az olduğu için palplanş uygulaması tek kademeli olarak analiz edilmiştir. Ayrıca bu çalışma kapsamında palplanşların yeniden kullanılabilme özelliği referans alınarak palplanş sisteminin 2 yıldan daha az süreli bir proje için kullanılacağı durum dikkate alınmış ve buna istinaden analizlere dinamik etkiler dahil edilmemiştir. Sonuç olarak 11296 adet farklı geometri durumu incelenerek her biri için amaç fonksiyonu olan maliyet fonksiyonları oluşturulmuş ve en düşük maliyeti veren optimum kesit bulunmaya çalışılmıştır.

\section{İksa Sistemindeki Ankraj Kuvvetleri ve Eğilme Mo- mentlerinin Hesaplanması}

Ankrajlı esnek duvarlar için zemin ankraj yükleri, Şekil 1 'de verilen görünür toprak basıncı zarflarından tahmin edilebilir. Statikçe belirsiz sistemler için oluşturulmuş hesapları ele alabilmek için geliştirilen yöntemlerden biri olan mafsal yöntemi, yaygın bir şekilde kullanılan yöntemlerdendir. Uygun görünür toprak basınç diyagramı kullanıldığında bu yöntem, yeterli dayanıma sahip zeminler içerisinde inşa edilen ankrajlı sistemler için zemin ankraj yüklerini ve duvar eğilme momentlerini makul sınırlar içerisinde tahmin etmektedir. Bu yöntem, kazı tabanında bir mafsal meydana geldiğini ve kazı altındaki zeminin de bir destek elemanı olarak etki ettiğini varsaymıştır. FHWA (1999), yeterli dayanıma sahip malzemeler içerisine penetre edilmiş duvarlar için bu iki varsayımın uygun olduğunu ifade etmiştir. Ayrıca bu yöntem, ilk 
sıradaki ankraj hariç diğer tüm ankraj seviyelerinde bir mafsal olduğunu varsaymaktadır.

Şekil (2)'de çok ankrajlı bir iksa sisteminin serbest cisim diyagramı gösterilmiştir.

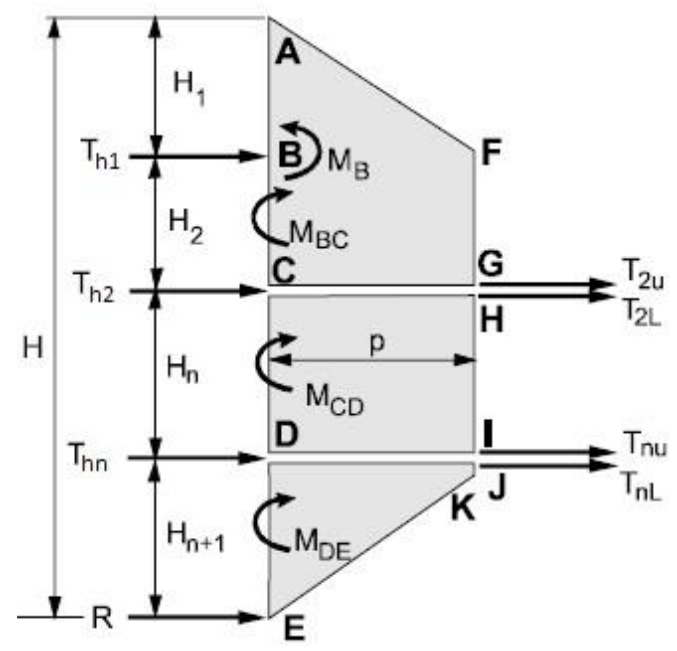

Şekil 2. Çok ankrajlı iksa duvarı için serbest cisim diyagramı (FHWA, 1999)

Şekil 2'de serbest cisim diyagramı gösterilen çok ankrajı bir iksa sistemi için ankraj kuvvetlerinin ve maksimum eğilme momentlerinin FHWA (1999) tarafından önerilen mafsal yöntemine göre hesabı aşağıdaki gösterilmiştir. Ankraj kuvvetlerinin hesap algoritması aşağıdaki gibidir.

1-) $\mathrm{T}_{\mathrm{h} 1}$ kuvvetini $\sum \mathrm{M}_{\mathrm{C}}=0$ 'dan hesapla

2-) $\mathrm{T}_{2 \mathrm{u}}=\mathrm{ABCGF}$ (toplam yük)- $\mathrm{T}_{\mathrm{h} 1}$

3-) $T_{2 L}$ kuvvetini $\sum M_{D}=0$ 'dan hesapla

4-) $\mathrm{T}_{\mathrm{nu}}=\mathrm{CDIH}$ (toplam yük)- $\mathrm{T}_{2 \mathrm{~L}}$

5-) $\mathrm{T}_{\mathrm{nL}}$ kuvvetini $\sum \mathrm{M}_{\mathrm{E}}=0$ 'dan hesapla

6-) $\mathrm{R}=$ Toplam yük- $\mathrm{T}_{\mathrm{h} 1}-\mathrm{T}_{\mathrm{h} 2}-\mathrm{T}_{\mathrm{hn}}$

7-) $\mathrm{T}_{\mathrm{h} 2}=\mathrm{T}_{2 \mathrm{u}}+\mathrm{T}_{2 \mathrm{~L}}$

8-) $\mathrm{T}_{\mathrm{hn}}=\mathrm{T}_{\mathrm{nu}}+\mathrm{T}_{\mathrm{nL}}$

Sıkı kumlar ve sert killer gibi yeterli dayanıma sahip zeminler içinde inşa edilen duvarlar için maksimum eğilme momenti duvarın açık kısmında meydana gelmekte ve bu momentler aşağıdaki şekilde hesaplanmaktadır (FHWA, 1999).

1-) $\mathrm{M}_{\mathrm{C}}=\mathrm{M}_{\mathrm{D}}=\mathrm{M}_{\mathrm{E}}=0$

2-) $\mathrm{M}_{\mathrm{B}}=\sum \mathrm{M}_{\mathrm{B}}$ hesapla

3-) $B$ ve $C$ arasında kesme kuvvetinin sıfır olduğu yerdeki maksimum eğilme momentini $\left(\mathrm{M}_{\mathrm{BC}}\right)$ hesapla

4-) Sırasıyla $C$ ve D ile D ve E arasında kesme kuvvetinin sıfır olduğu yerdeki maksimum eğilme momentlerini $\left(\mathrm{M}_{\mathrm{CD}}\right)$ ve $\left(\mathrm{M}_{\mathrm{DE}}\right)$ hesapla
Ankraj yükleri için Şekil 1 ve Şekil 2 kullanılarak hesaplanan değerler, duvarın birim genişliği başına etki eden ve ankraj yükünün yatay bileşeni olan $\mathrm{T}_{\text {hi }}$ değeridir. Toplam yatay ankraj yükü $\mathrm{T}_{\mathrm{h}}$ ise Eşitlik (3)'teki gibi hesaplanır:

$$
\mathrm{T}_{\mathrm{h}}=\mathrm{T}_{\mathrm{hi}}{ }^{*} \mathrm{~s}
$$

Burada s, ankrajlar arasındaki mevcut yatay aralık değeridir.

Ankraj kök bölgesinin tasarımında kullanılan toplam ankraj yükü $(T)$ ise Eşitlik (4)'ten hesaplanır:

$$
\mathrm{T}=\frac{\mathrm{T}_{\mathrm{h}}}{\cos \theta}
$$

Burada $\theta$, ankrajın yatayla yaptığı eğim açısıdır.

Toplam ankraj kuvvetinin düşey bileşeni $T_{v}$, Eşitlik (5)'ten hesaplanır:

$$
\mathrm{T}_{\mathrm{v}}=\mathrm{T}^{*} \sin \theta
$$

İki ankrajlı iksa sistemi için ankraj kuvvetleri, reaksiyon kuvveti ve maksimum eğilme momenti hesabı

İki ankrajlı bir iksa sistemi için hesaba esas olan serbest cisim diyagramı Şekil 4'te gösterilmiştir.

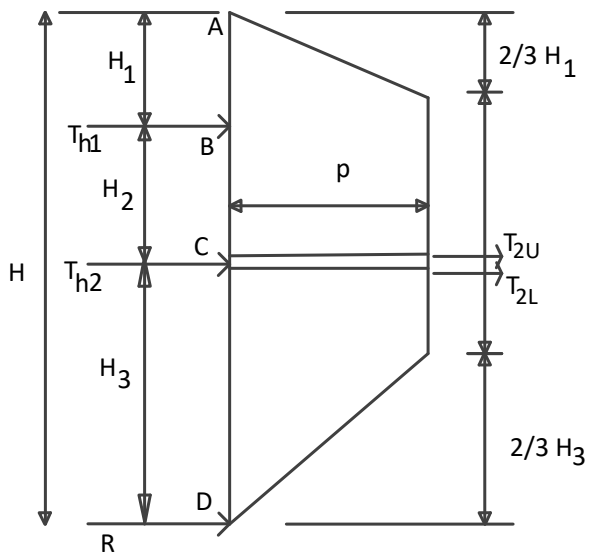

Şekil 3. İki ankrajlı iksa sistemi için serbest cisim diyagramı

Şekil 3'teki serbest cisim diyagramı dikkate alınarak oluşturulan ve yatay ankraj kuvvetlerini veren denklemler aşağıdaki gibidir: 


$$
\begin{aligned}
& \mathrm{T}_{\mathrm{h} 1}=\left(\frac{13 \mathrm{H}_{1}^{2}}{54}+\frac{\mathrm{H}_{2}^{2}}{2}+\frac{2 \mathrm{H}_{1} * \mathrm{H}_{2}}{3}\right) * \frac{\mathrm{p}}{\mathrm{H}_{2}}+\left(\mathrm{q} * \mathrm{~K}_{\mathrm{a}} *\left(\mathrm{H}_{1}+\mathrm{H}_{2}\right)^{2}\right) * \frac{1}{2 \mathrm{H}_{2}} \\
& \mathrm{~T}_{2 \mathrm{u}}=\left(\frac{2 \mathrm{H}_{1}}{3}+\mathrm{H}_{2}\right) * \mathrm{p}+\left(\mathrm{q}^{*} \mathrm{~K}_{\mathrm{a}} *\left(\mathrm{H}_{1}+\mathrm{H}_{2}\right)\right)-\mathrm{T}_{\mathrm{h} 1} \\
& \mathrm{~T}_{2 \mathrm{~L}}=\left(\frac{23 \mathrm{H}_{3} * \mathrm{p}}{54}+\frac{\mathrm{q}^{*} \mathrm{~K}_{\mathrm{a}} * \mathrm{H}_{3}}{2}\right)
\end{aligned}
$$

Hesaplamalarda kullanılan $K_{a}$ ve $K_{p}$ değerleri için Rankine tarafından önerilen aşağıdaki eşitlikler kullanılmıştır:

$$
\begin{aligned}
& \mathrm{K}_{\mathrm{a}}=\tan ^{2}\left(45-\frac{\varnothing}{2}\right) \\
& \mathrm{K}_{\mathrm{p}}=\tan ^{2}\left(45+\frac{\varnothing}{2}\right)
\end{aligned}
$$

Burada $\mathrm{T}_{\mathrm{h} 1}$, en üstteki ankraja (1. ankraj) gelen yatay kuvveti; $\mathrm{T}_{2 \mathrm{u}}$ ve $\mathrm{T}_{2 \mathrm{~L}}, 2$. ankraja gelen yatay kuvvetin bile- şenlerini; $p$, duvara etkiyen toprak basıncı zarfının maksimum basınç ordinatını; $\mathrm{H}_{1}$, zemin yüzeyi ile 1. ankraj arasındaki düşey mesafeyi; $\mathrm{H}_{2}, 1$. ankraj ile 2. ankraj arasındaki düşey mesafeyi; $\mathrm{H}_{3}$, en alttaki ankraj ile kazı tabanı arasındaki düşey mesafeyi; $\mathrm{K}_{\mathrm{p}}$, pasif toprak basıncı katsayısını ve $q$ ise üniform yayılı sürşarj yükünü göstermektedir.

İki ankrajlı bir iksa sistemi için maksimum eğilme momenti, ankrajların konumlarına ve ankrajlara gelen kuvvetlere bağlı olarak duvarın farklı lokasyonlarında meydana gelebileceği için, kuvvetin ve/veya kesit geometrisinin değiştiği her lokasyon için ayrı ayrı denklemler oluşturulmuştur.

$$
\begin{aligned}
& \mathrm{H}_{1} \leq \mathrm{x}_{2} \leq \mathrm{H}_{1}+\mathrm{H}_{2} \text { ise } \\
& \mathrm{x}_{2}=\left(\mathrm{T}_{\mathrm{h} 1}+\left(\frac{\mathrm{p} * \mathrm{H}_{1}}{3}\right)\right) /\left(\mathrm{p}+\mathrm{q}^{*} \mathrm{~K}_{\mathrm{a}}\right) \\
& \mathrm{M}_{\max }=\left(\mathrm{T}_{\mathrm{h} 1} *\left(\mathrm{x}_{2}-\mathrm{H}_{1}\right)\right)-\left(\frac{\mathrm{H}_{1} * \mathrm{p}}{3} *\left(\mathrm{x}_{2}-\frac{4 \mathrm{H}_{1}}{9}\right)\right)-\left(\mathrm{x}_{2}-\frac{2 \mathrm{H}_{1}}{3}\right)^{2} * \frac{\mathrm{p}}{2}-\left(\frac{\mathrm{q}^{*} \mathrm{~K}_{\mathrm{a}} * \mathrm{x}_{2}^{2}}{2}\right) \\
& \mathrm{H}_{1}+\mathrm{H}_{2} \leq \mathrm{x}_{2} \leq \mathrm{H}_{1}+\mathrm{H}_{2}+\frac{\mathrm{H}_{3}}{3} \text { ise; } \\
& \mathrm{x}_{2}=\left(\mathrm{T}_{\mathrm{h} 1}+\mathrm{T}_{\mathrm{h} 2}+\left(\frac{\mathrm{p}^{*} \mathrm{H}_{1}}{3}\right)\right) /\left(\mathrm{p}+\mathrm{q}^{*} \mathrm{~K}_{\mathrm{a}}\right) \\
& \mathrm{M}_{\max }=\left(\mathrm{T}_{\mathrm{h} 1} *\left(\mathrm{x}_{2}-\mathrm{H}_{1}\right)\right)+\left(\mathrm{T}_{\mathrm{h} 2} *\left(\mathrm{x}_{2}-\mathrm{H}_{1}-\mathrm{H}_{2}\right)\right)-\left(\frac{\mathrm{H}_{1} * \mathrm{p}}{3} *\left(\mathrm{x}_{2}-\frac{4 \mathrm{H}_{1}}{9}\right)\right)-\left(\mathrm{x}_{2}-\frac{2 \mathrm{H}_{1}}{3}\right)^{2} * \frac{\mathrm{p}}{2}-\left(\frac{\mathrm{q}^{*} \mathrm{~K}_{\mathrm{a}} * \mathrm{x}_{2}^{2}}{2}\right)
\end{aligned}
$$




$$
\begin{aligned}
& \frac{\mathrm{H}_{1}+\mathrm{H}_{2}+\frac{\mathrm{H}_{3}}{3} \leq \mathrm{x}_{2} \leq \mathrm{H} \text { ise; }}{\frac{\mathrm{H}_{1} * \mathrm{p}}{3}+\left(\frac{\mathrm{H}_{1}}{3}+\mathrm{H}_{2}+\frac{\mathrm{H}_{3}}{3}\right) * \mathrm{p}+\left(\mathrm{x}_{2}-\mathrm{H}_{1}-\mathrm{H}_{2}-\frac{\mathrm{H}_{3}}{3}\right) *\left(\frac{\mathrm{p}+\mathrm{k}}{2}\right)+\left(\mathrm{q}^{*} \mathrm{~K}_{\mathrm{a}} * \mathrm{x}_{2}\right)-\mathrm{T}_{\mathrm{h} 1}-\mathrm{T}_{\mathrm{h} 2}=0} \\
& \mathrm{k}=\frac{3 \mathrm{p} *\left(\mathrm{H}-\mathrm{x}_{2}\right)}{2 \mathrm{H}_{3}} \\
& \quad \mathrm{M}_{\text {max }}=\left(\mathrm{T}_{\mathrm{h} 1} *\left(\mathrm{x}_{2}-\mathrm{H}_{1}\right)\right)+\left(\mathrm{T}_{\mathrm{h} 2} *\left(\mathrm{x}_{2}-\mathrm{H}_{1}-\mathrm{H}_{2}\right)\right)-\left(\frac{\mathrm{H}_{1} * \mathrm{p}}{3} *\left(\mathrm{x}_{2}-\frac{4 \mathrm{H}_{1}}{9}\right)\right)-\left(\mathrm{x}_{2}-\frac{2 \mathrm{H}_{1}}{3}\right)^{2} * \frac{\mathrm{p}}{2}-\left(\frac{\mathrm{q}^{*} \mathrm{~K}_{\mathrm{a}} * \mathrm{x}_{2}^{2}}{2}\right) \\
& \quad-\left(\frac{\mathrm{p}-\mathrm{k}}{6}\right) *\left(\mathrm{x}_{2}-\mathrm{H}_{1}-\mathrm{H}_{2}-\left(\frac{\mathrm{H}_{3}}{3}\right)\right)^{2} \\
& \begin{array}{l}
\text { Burada } \mathrm{M}_{\text {max }}, \text { duvara gelen maksimum eğilme momen- } \\
\text { tini; } \mathrm{x}_{2}, \text { iki ankrajlı bir iksa sisteminde, zemin yüzeyinden } \\
\text { kesme kuvvetinin sıfır olduğu yere olan düşey mesafeyi }
\end{array}
\end{aligned}
$$
temsil etmektedir.

İki ankrajlı bir iksa sistemi için, kazı altındaki zemin tarafından direnilmesi gereken reaksiyon kuvveti Eşitlik (18)'deki gibidir:

$$
\mathrm{R}_{2}=\left(\frac{2 \mathrm{H}_{1}}{3}+\mathrm{H}_{2}+\frac{2 \mathrm{H}_{3}}{3}\right) * \mathrm{p}+\left(\mathrm{q} * \mathrm{~K}_{\mathrm{a}} * \mathrm{H}\right)-\mathrm{T}_{\mathrm{h} 1}-\mathrm{T}_{\mathrm{h} 2}
$$

En üstteki ankraj lokasyonunda meydana gelen eğilme momenti $\left(\mathrm{M}_{\mathrm{B}}\right)$, Eşitlik (19)'dan hesaplanır:

$$
\mathrm{M}_{\mathrm{B}}=\frac{13 \mathrm{H}_{1}^{2} * \mathrm{p}}{54}
$$

Yukarıda iki ankrajlı iksa sistemi için tanımlanan maksimum eğilme momenti değeri hesaplanıp $M_{B}$ ile karşılaştırılacak ve büyük olan moment değeri ilgili duvara gelen maksimum eğilme momenti olarak seçilecektir (FHWA, 1999).

\section{Hesaplanan maksimum eğilme momentine göre du- var kesitinin seçilmesi}

Uygun duvar kesitinin seçimi, düşey duvar elemanında hesaplanan maksimum eğilme momentine bağlıdır. Buna nedenle ilk sıradaki ankraj konumunda meydana gelen negatif eğilme momenti ile her bir ankraj arasında hesaplanan pozitif eğilme momentlerinden mutlak değerce büyük olanı kesit seçiminde kullanılmıştır. Duvar seçimi için gerekli minimum kesit modülü $S_{\min }$, Eşitlik (20)'deki gibi hesaplanır:
Kritik olduğu düşünülen geçici ve kalıcı duvar durumu için, FHWA (1999) tarafından asker kazığın veya palplanşın müsaade edilebilir eğilme gerilmesinin $\left(F_{b}\right)$, $0,55 \mathrm{~F}_{\mathrm{y}}$ değerine eşit olarak alınması tavsiye edilmektedir. Burada $F_{y}$ çeliğin akma gerilmesidir. Çelik palplanş ve asker kazıklar için yaygın bir şekilde ya Derece 36 $\left(F_{y}=248 \mathrm{MPa}\right)$ ya da Derece $50\left(F_{y}=345 \mathrm{MPa}\right)$ malzeme kullanılmaktadır (FHWA, 1999).

\section{Duvarın Çakma Derinliğinin Hesaplanması}

Sürekli palplanş duvarların analizleri için pasif direnç hesaplanırken, Eşitlik (18)'den hesaplanan ve kazı tabanı altındaki zemin tarafından direnilmesi gereken reaksiyon kuvveti olan $\mathrm{R}$ ile karşılaştırıldığında pasif toprak basıncı katsayısı 1,5'lik bir güvenlik faktörü ile azaltılmıştır. Ayrıca kohezyonsuz zeminler içerisinde gerekli gömme derinliğinin hesaplanması için kazı tabanının altında, asker kazığının genişliği üzerine veya palplanşın birim genişliği üzerine etki eden aktif toprak basıncı da itici bir kuvvet olarak dikkate alınmıştır (FHWA, 1999). Bu durumlar göz önünde bulundurularak çakma derinliği için Eşitlik (21) oluşturulmuştur.

$$
\frac{\gamma_{\mathrm{n}} * \mathrm{~K}_{\mathrm{p}} * \mathrm{D}^{2}}{3}=\frac{\gamma_{\mathrm{n}} * \mathrm{~K}_{\mathrm{a}} * \mathrm{D}^{2}}{2}+\mathrm{R}+\mathrm{q} * \mathrm{~K}_{\mathrm{a}} * \mathrm{D}
$$

Burada $D$, çakma derinliğini, $\gamma_{n}$, zeminin doğal birim hacim ağırlığını, R, kazı tabanı altındaki zeminin direnmesi gereken reaksiyon kuvvetini temsil etmektedir. 


\section{Ankrajlı İksa Sisteminin Tasarımında Kullanılan Sınır Fonksiyonları}

Bu çalışma kapsamında, iksa sisteminin geometrisinin seçiminde, FHWA (1999) ve BS (1989) tarafından önerilen sınır koşulları dikkate alınarak oluşturulan ve aşağıdaki şekilde tarif edilen denklemler kullanılmıştır. Ankraj kök bölgesinin, duvar arkasındaki göçme düzleminin dışına uzanması için gerekli minimum gövde uzunluğunun tarifi için Eşitlik (22) kullanılmıştır.

$$
\mathrm{L}_{\text {gövde }}[\mathrm{j}]=\left(\frac{\left(\mathrm{H}-\left[\sum_{\mathrm{i}=1}^{\mathrm{j}} \mathrm{H}_{\mathrm{i}}\right]\right) * \sin \left(45-\frac{\varnothing}{2}\right)+\mathrm{x}}{\sin \left(45+\theta+\frac{\varnothing}{2}\right)}\right)
$$

$$
\left(\begin{array}{l}
x=1.5 \mathrm{~m}, \mathrm{H}<7.5 \mathrm{~m} \\
\mathrm{x}=0.2 \mathrm{H}, \mathrm{H} \geq 7.5 \mathrm{~m}
\end{array}\right)
$$

Burada $L_{\text {gövde }}[j]$, i. ankraja ait minimum ankraj gövde uzunluğunu; $\mathrm{H}_{\mathrm{i}}$, Şekil 4 'te gösterilen ankraj düşey mesafelerini; $\theta$, ankrajın yatayla yaptığı açıyı temsil etmektedir. Bu çalışma kapsamında ankraj açıları $15^{\circ}, 20^{\circ}, 25^{\circ}$ ve $30^{\circ}$ olarak seçilmiştir. FHWA (1999), ankraj gövdesinde halat kullanılması durumunda minimum gövde uzunluğunun 4.5 m'den daha az olmaması gerektiğini önermiştir. Bu nedenle Eşitlik (22)'den elde edilen minimum gövde uzunlukları 4.5 m'den küçük çıktığında 4.5 m'ye eşit alınmıştır. Ayrıca ankrajlar arasındaki düşey mesafenin 2 m'ye eşit veya daha büyük olduğu varsayılmıştır (BS, 1989). Hesaplanan ankraj kuvvetlerine göre ankrajlarda kullanılması gerekli minimum halat sayılarının seçimi için Tablo (1)'deki değerler kullanılmıştır.

Tablo 1. 15 mm (0,6") çapa sahip öngermeli çelik halatların özellikleri (FHWA, 1999)

\begin{tabular}{|c|c|c|c|c|c|}
\hline $\mathbf{1 5} \mathbf{~ m m}$ çaplı halat sayısı & Enkesit alanı $\left(\mathbf{A}_{\mathbf{p s}}\right)$ & Nihai dayanımı (f & \multicolumn{3}{|c|}{ Öngerme kuvveti } \\
\hline & & & $0.8 \mathrm{f}_{\mathrm{pu}} \mathrm{A}_{\mathrm{ps}}$ & $0.7 \mathrm{f}_{\mathrm{pu}} \mathrm{A}_{\mathrm{ps}}$ & $0.6 \mathrm{f}_{\mathrm{pu}} \mathrm{A}_{\mathrm{ps}}$ \\
\hline & & $(\mathrm{kN})$ & $(\mathrm{kN})$ & $(\mathrm{kN})$ & $(\mathrm{kN})$ \\
\hline 1 & $\left(\mathrm{~mm}^{2}\right)$ & 260.7 & 209 & 182 & 156 \\
\hline 3 & 140 & 782.1 & 626 & 547 & 469 \\
\hline 4 & 420 & 1043 & 834 & 730 & 626 \\
\hline 5 & 560 & 1304 & 1043 & 912 & 782 \\
\hline 7 & 700 & 1825 & 1460 & 1277 & 1095 \\
\hline 12 & 980 & 2346 & 1877 & 1642 & 1408 \\
\hline 15 & 1260 & 3128 & 2503 & 2190 & 1877 \\
\hline 19 & 1680 & 3911 & 3128 & 2737 & 2346 \\
\hline
\end{tabular}

Hesaplanan ankraj kuvvetlerine bağlı olarak sıyrılmaya karşı gerekli minimum kök uzunluğunun belirlenmesi aşamasında ise Tablo 2'de orta sıkı kumlar için önerilen değer kullanılmıştır. Buna bağlı olarak oluşturulan kısıt fonksiyonu Eşitlik (24)'teki gibidir:

$$
\mathrm{T}_{\mathrm{i}} \leq 145 \mathrm{~L}_{\mathrm{kök}}
$$

Burada $\mathrm{T}_{\mathrm{i}}$, ilgili ankraja gelen kuvveti, $\mathrm{L}_{\mathrm{kök}}$ ise gerekli minimum ankraj kök bölgesi uzunluğudur. 
Tablo 2. Küçük çaplı, kendi ağırlığı ile yerleşen düz şaftı zemin ankrajlarının ön tasarımı için yük transferinin tahmini nihai değerleri (FHWA, 1999)

\begin{tabular}{|l|l|c|}
\hline \multicolumn{1}{|c|}{ Zemin Türü } & Nispi Sıkılık (SPT aralığı) & Tahmin edilen transfer yükü (kN/m) \\
\hline \multirow{3}{*}{ Kum ve çakıl } & Gevşek (4-10) & 145 \\
& Orta sıkı (11-30) & 220 \\
& Sıkı (31-50) & 290 \\
\hline \multirow{3}{*}{ Kum } & Gevşek (4-10) & 100 \\
& Orta sıkı (11-30) & 145 \\
\hline \multirow{3}{*}{ Kum ve silt } & Sıkı (31-50) & 190 \\
\hline Düşük plastisiteye sahip silt-kil karı- & Gevşek (4-10) & 70 \\
şımı veya ince mikalı kum ya da silt & Orta sıkı (11-30) & 100 \\
karışımları & Katı (10-20) & 30 \\
\hline
\end{tabular}

Not: SPT değerleri örtü basıncı için düzeltilmiştir.

En üstteki ankrajın kök bölgesi üzerinde FHWA (1999) tarafından önerilen 4,5 m'lik minimum örtü basıncının meydana gelmesi için, ilk ankrajın konumuna bağlı olarak Eşitlik (25)'teki koşulun sağlanıp sağlanmadığı araştırılmıştır. Koşul sağlanmadığında koşul sağlanana kadar ankraj kök bölgesinin uzunluğunun arttırılması işlemine gidilmiştir.

$$
\mathrm{H}_{1} \geq 4.5-\left(\frac{\mathrm{L}_{\mathrm{kök} 1}}{2}+\mathrm{L}_{\text {gövde1 }}\right) * \sin \theta_{1}
$$

Burada $\mathrm{H}_{1}$, en üst sıradaki ankrajın zemin üst yüzeyine olan düşey mesafesini; $L_{k o ̈ k 1}$, en üst sıradaki ankraja ait kök uzunluğunu; $\mathrm{L}_{\text {gövde1 }}$, en üst sıradaki ankraja ait gövde uzunluğunu ve $\theta_{1}$ ise en üst sıradaki ankrajın yatayla yaptığı eğim açısını temsil etmektedir.

Ankrajın üst bölgesinden ankrajın sonuna doğru yük transferi için özel yöntemler kullanılmadıkça yaklaşık olarak 12 m'den daha büyük kök uzunlukları için ankraj kapasitesinde bir artış elde edilemediğinden dolayı ankraj kök uzunlukları genellikle 4,5 ile $12 \mathrm{~m}$ aralığında seçilmektedir (FHWA, 1999). Bu nedenle analizlerde minimum ankraj kök bölgesi uzunluğu 4,5 m olarak seçilmiştir.

\section{Ankrajlı İksa Sisteminin Amaç Fonksiyonu}

Ankrajlı palplanş duvarın optimum maliyetinin araştırılmasında kullanılan amaç fonksiyonu (toplam maliyet) Eşitlik (26)'da gösterilmiştir:

Toplam Maliyet=Palplanş Toplam Maliyeti (PTM)+Ankraj Toplam Maliyeti (ATM)+Kuşak Maliyeti (KM)

$$
\mathrm{PTM}=2 *(\mathrm{~B}+\mathrm{L}) *(\mathrm{H}+\mathrm{D}) * \mathrm{PBM}
$$

$$
\operatorname{ATM}=\left(\sum_{\mathrm{i}=1}^{\mathrm{n}}\left(\mathrm{L}_{\text {gövde }}[\mathrm{i}]+\mathrm{L}_{\mathrm{kök}}[\mathrm{i}]\right) * \operatorname{ABM}[\mathrm{i}]\right) * \mathrm{~N}
$$

$$
\mathrm{KM}=\mathrm{KBM}^{*} \mathrm{n}^{*} \mathrm{KA}
$$

Burada PBM, bu çalışma kapsamında kullanılan Larssen tipi palplanş kesitleri için İller Bankası tarafından önerilen güncel palplanş birim fiyatını; $\mathrm{KM}$, kuşak maliyetini; KBM, kuşak birim maliyetini; n, kuşak sayısını; KA, kuşak ağırlığını; B, kazı genişliğini; L, kazı uzunluğunu; (H+D) toplam palplanş boyunu; ATM, ankraj toplam maliyetini; $\mathrm{N}$, yatay sırada kullanılan ankraj sayısını; $\mathrm{L}_{\text {gövde }}[\mathrm{i}]$, i. ankraja ait gövde uzunluğunu; $\mathrm{L}_{\mathrm{kök}}[\mathrm{i}]$, i. ankraja ait kök uzunluğunu ve $A B M[i]$ ise $i$. ankraja ait güncel ankraj birim maliyetini temsil etmektedir.

Palplanşlar için bu çalışmada kullanılan 2018 yılına ait birim fiyat tarifleri malzeme ve ekipman bedeli, çakma ve sökme işlemleri ile tüm işçilik giderleri dahil olmak üzere Tablo 3'te verilmiştir. Burada, İller Bankasındaki 20.011/A-(1,2,3,4,5,6,7 ve 8) poz numaralarına ait birim fiyatlar kullanılmıştır.

Tablo 3. İller Bankası tarafından önerilen palplanş birim fiyatları

\begin{tabular}{|c|c|}
\hline Palplanş Türü & Birim Maliyet (TL/ $\mathbf{m}^{\mathbf{2}}$ ) \\
\hline Larssen 22 & 241.35 \\
\hline Larssen 23 & 264.59 \\
\hline Larssen 24 & 278.65 \\
\hline Larssen 25 & 300.44 \\
\hline Larssen VI & 359.51 \\
\hline Larssen VII & 373.57 \\
\hline
\end{tabular}


Malzeme ve ekipman bedeli ile tüm işçilik giderleri dahil olmak üzere halat sayısına bağlı olarak $15 \mathrm{~mm}(0.6 ")$ çapında öngermeli halatlar ile yapılan ankrajlar için bu çaIışmada kullanılan ve piyasadan sağlanan ortalama 2018 yılına ait birim fiyatlar ise Tablo 4'te verilmiştir.

Tablo 4. Piyasadan sağlanan ortalama ankraj birim fiyatları

\begin{tabular}{|c|c|}
\hline Halat SayıSı & Birim Maliyet (TL/m) \\
\hline $3^{\star} 0.6 "$ & 76.26 \\
\hline $4^{\star} 0.6 "$ & 89.39 \\
\hline $5^{\star} 0.6 "$ & 108.89 \\
\hline $7^{\star} 0.6 "$ & 135.09 \\
\hline $9^{\star} 0.6 "$ & 161.29 \\
\hline
\end{tabular}

Kuşak maliyeti hesabı içinse yine İller Bankasındaki 23.245/IB-1 poz nolu 2018 yılına ait birim fiyat tarifi kullanılmıştır. Bu tarife göre; her türlü işçilik, genel gider ve malzeme fiyatları dahil olmak üzere kuşağın ton fiyatı 1727.31 TL'dir

\section{Hesaplarda Kullanılan Zemin ve İksa Elemanlarının Özellikleri ve Yapılan Kabuller}

Optimum maliyette kesitin belirleneceği elle hesap aşamasında, palplanş elemanlarının çakılacağı zeminin doğal birim hacim ağırlığının $18 \mathrm{kN} / \mathrm{m}^{3}$, içsel sürtünme açısının 36 derece olduğu ve yer altı su seviyesinin çok derinlerde (25 m'nin altında) olduğu varsayılmıştır. Palplanş kesiti olarak ise, yaygın bir şekilde kullanılan ve 30 ile $35 \mathrm{~m}$ uzunluğa kadar üretilebilen ve akma dayanımı $345 \mathrm{MPa}$ olan Larssen tipi (U kesitli) çelik palplanş sınıfı içerisinden Larssen 22, Larssen 23, Larssen 24, Larssen 25, Larssen VI ve Larssen VII türü palplanşlar kullanılmıştır. Palplanşların müsaade edilebilir eğilme gerilmesinin, FHWA (1999) tarafından önerildiği gibi, çelik palplanşın akma dayanımının \%55'ine eşit olduğu kabul edilmiştir. Ankraj için ise 0,6 inç $(\approx 15 \mathrm{~mm})$ çapındaki Tip 270 öngermeli çelik halatlar kullanıımıştır. Ayrıca analizlerde, PLAXIS 3D Foundation Tutorial Manual Version 2 'de kullanıldığı gibi $86,82 \mathrm{~cm}^{2}$ kesit alanına ve de 7,8 $\mathrm{t} / \mathrm{m}^{3}$ birim hacim ağırlığa sahip kuşak kullanılmıştır.

Optimizasyon hesaplarında geçici kazı durumu dikkate alındığı için hesaplara dinamik kuvvetler eklenmemiştir. Ayrıca uygulamada genellikle en az 3 halatlı ankraj kullanıldığı için, analizlerde 3 'ten daha az sayıda halat gerektiren ankraj kuvvetleri durumunda halat sayıları 3 alınmıştır.

Bu çalışmada uygun palplanş kesitinin seçiminde Tablo 5 'ten faydalanılmıştır.
Tablo 5. Larssen tipi (U kesitli) bazı palplanşlara ait minimum kesit modülleri

\begin{tabular}{|c|c|}
\hline $\begin{array}{c}\text { Palplanş } \\
\text { türü }\end{array}$ & $\begin{array}{c}\text { Minimum kesit modülü }\left(\mathbf{S}_{\text {min }}\right) \\
\left.\left(\mathbf{c m}^{\mathbf{3}}\right) / \mathbf{m}\right)\end{array}$ \\
\hline Larssen 22 & 1260 \\
\hline Larssen 23 & 2000 \\
\hline Larssen 24 & 2500 \\
\hline Larssen 25 & 3040 \\
\hline Larssen VI & 4200 \\
\hline Larssen VII & 5010 \\
\hline
\end{tabular}

\section{ARAŞTIRMA BULGULARI}

Yapılan analizler neticesinde, en üst ankrajın zemin üst yüzeyine olan düşey mesafesinin $\left(\mathrm{H}_{1}\right)$ ve ankrajlar arası düşey mesafenin $\left(\mathrm{H}_{2}\right)$ değişiminin ankraj kuvvetlerine, gerekli minimum ankraj gövdesi uzunluklarına, maksimum eğilme momentlerine, çakma derinliklerine ve de palplanş sisteminin toplam maliyetine etkisini gösteren grafikler aşağıda sunulmuştur.

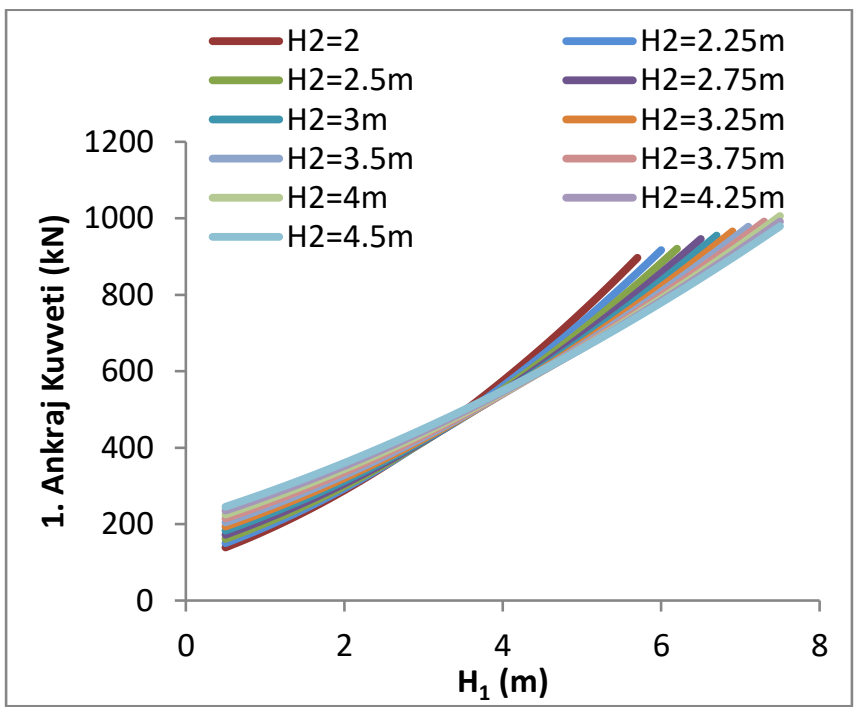

Şekil 4. $H=15 m$ ve $n=2$ olan palplanşta ankrajların düşey mesafelerinin 1. ankraj kuvvetine etkisi

Şekil 4'te her bir $\mathrm{H}_{2}$ değerine ait eğrilere bakıldığında $\mathrm{H}_{1}$ değerinin artması ile 1. ankraj kuvvetinin arttığı görülmektedir. Öte yandan belirli bir $\mathrm{H}_{1}$ değerine kadar (yaklaşık olarak 3,5 $\mathrm{m}<\mathrm{H}_{1}<4 \mathrm{~m}$ ) aynı $\mathrm{H}_{1}$ değerlerine karşılık farklı $\mathrm{H}_{2}$ değerleri için 1. ankraj kuvvetinin değişimi incelendiğinde, $\mathrm{H}_{2}$ değerinin artması ile 1. ankraj kuvveti artmıştır. Ancak belirli bir $\mathrm{H}_{1}$ değerinden sonra $\left(\mathrm{H}_{1}>3,5 \sim 4\right.$ $\mathrm{m}$ ) ise $\mathrm{H}_{2}$ değerinin artması ile 1. ankraj kuvveti azalmıştır. 


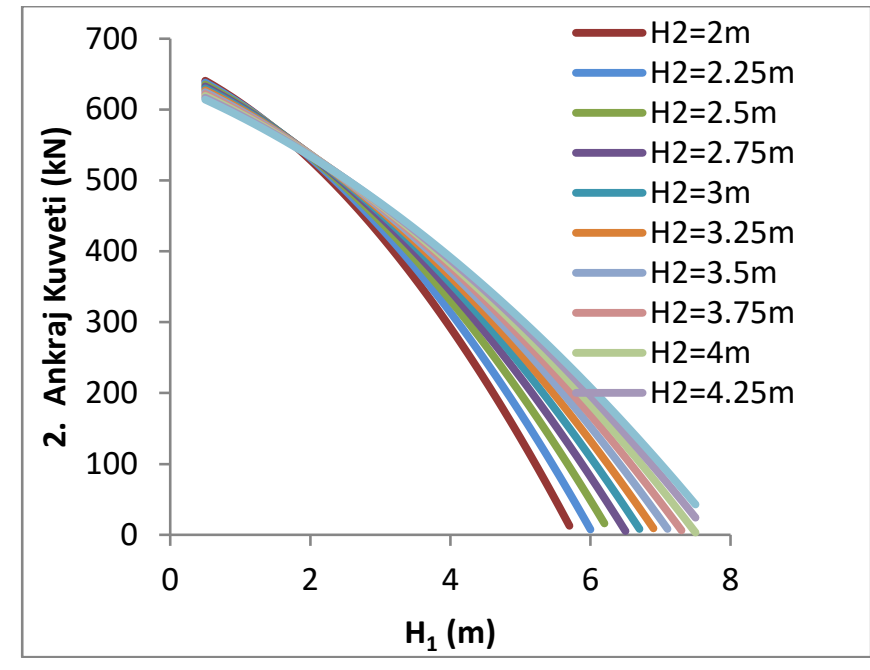

Şekil 5. $H=15 m$ ve $n=2$ olan palplanşta ankrajların düşey mesafelerinin 2. ankraj kuvvetine etkisi

Şekil 5'e göre, $\mathrm{H}_{1}$ değeri 1,5 $\mathrm{m} \sim 2 \mathrm{~m}$ aralığında iken aynı $\mathrm{H}_{1}$ 'e karşılık gelen farklı $\mathrm{H}_{2}$ değerleri incelendiğinde $\mathrm{H}_{2}$ değeri arttıkça 2. ankraj kuvvetinin azaldığı görülmektedir. Ancak $\mathrm{H}_{1}$ değeri yaklaşık olarak 2 m'yi geçtiğinde $\mathrm{H}_{2}$ değerinin artması ile 2. ankraj kuvveti artmıştır. Her bir $\mathrm{H}_{2}$ değerine ait eğrilere bakıldığında ise $\mathrm{H}_{1}$ değerinin artması ile 2. ankraj kuvvetinin daima azaldığı görülmektedir.

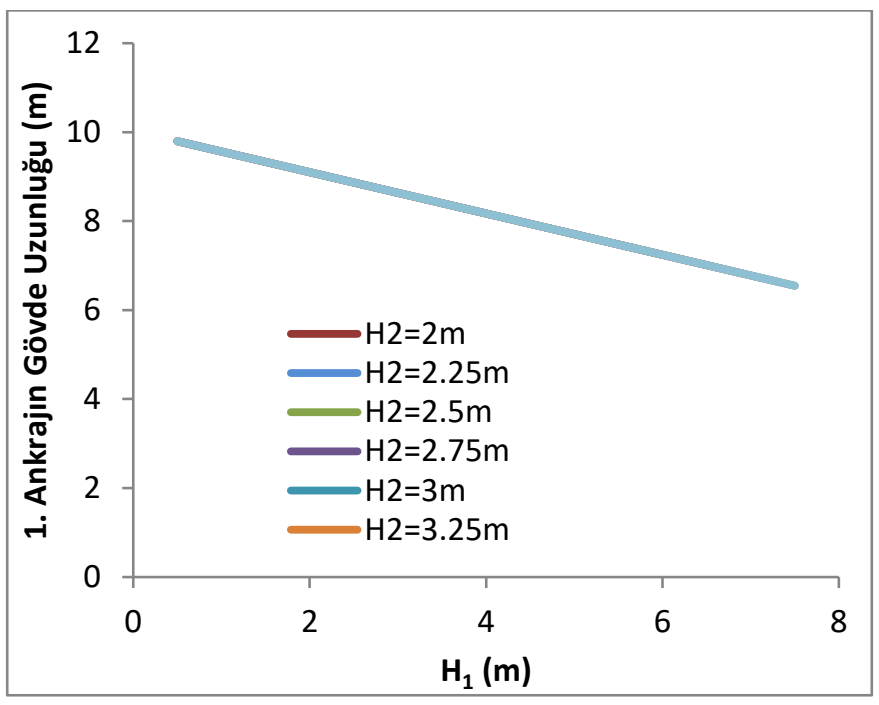

Şekil 6. $H=15 m$ ve $n=2$ olan palplanşta ankrajların düşey mesafelerinin 1. ankrajın minimum gövde uzunluğuna etkisi

Şekil 6'ya bakıldığında, 1. ankraj için gerekli minimum gövde uzunluğunun $\mathrm{H}_{2}$ değerinden bağımsız olduğu görülmektedir. 1. ankraj için gerekli minimum gövde uzunluğu sadece $\mathrm{H}_{1}$ 'in değişiminden etkilenmektedir. Sonuç olarak $\mathrm{H}_{1}$ değerinin artması ile azalmaktadır. Çünkü ankraj kök bölgesinin, duvarın kazı tabanı çizgisinden başlayarak yatayla $45+\emptyset / 2^{0}$ lik açı yapan aktif göçme düzleminin dışına uzanması için gerekli minimum ankraj gövde uzunluğu, duvar tabanına yaklaşıldıkça küçülecektir.

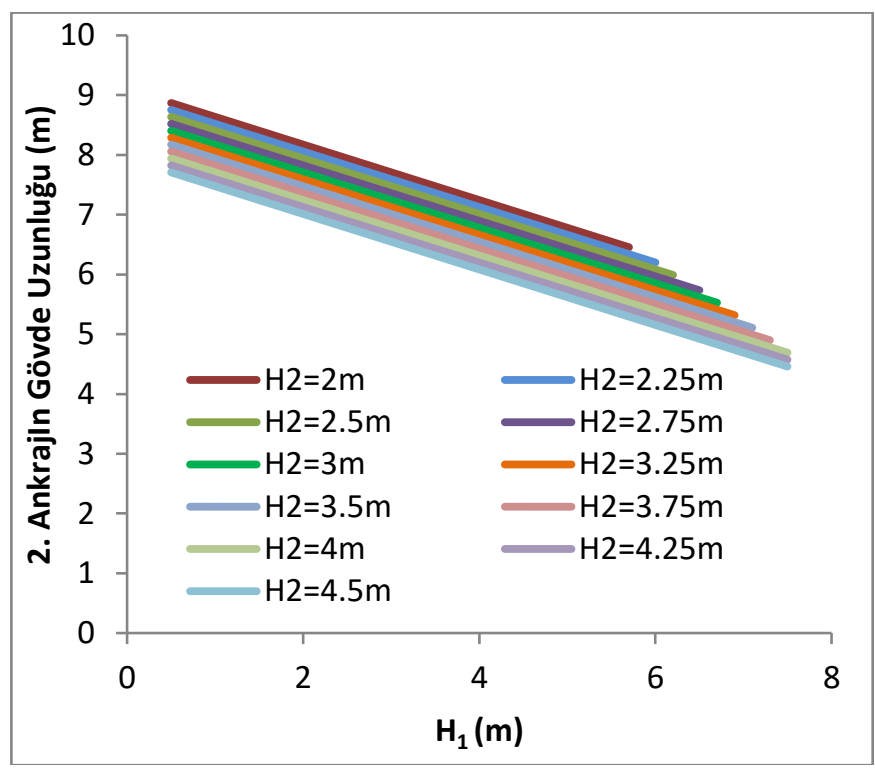

Şekil 7. $H=15 m$ ve $n=2$ olan palplanşta ankrajların düşey mesafelerinin 2. ankrajın minimum gövde uzunluğuna etkisi

Şekil 7'nin sonucu olarak, $\mathrm{H}_{1}$ ve $\mathrm{H}_{2}$ değerlerinin artması ile 2. ankraj için gerekli minimum gövde uzunluğu azalmaktadır. $\mathrm{H}_{1}$ ve $\mathrm{H}_{2}$ değerlerinin artması ile ikinci ankraj kazı tabanına yaklaşmakta ve bunun sonucunda ankraj kök bölgesinin yukarıda bahsi geçen aktif göçme kamasının dışına çıkabilmesi için gerekli minimum uzunluk da küçülmektedir. 


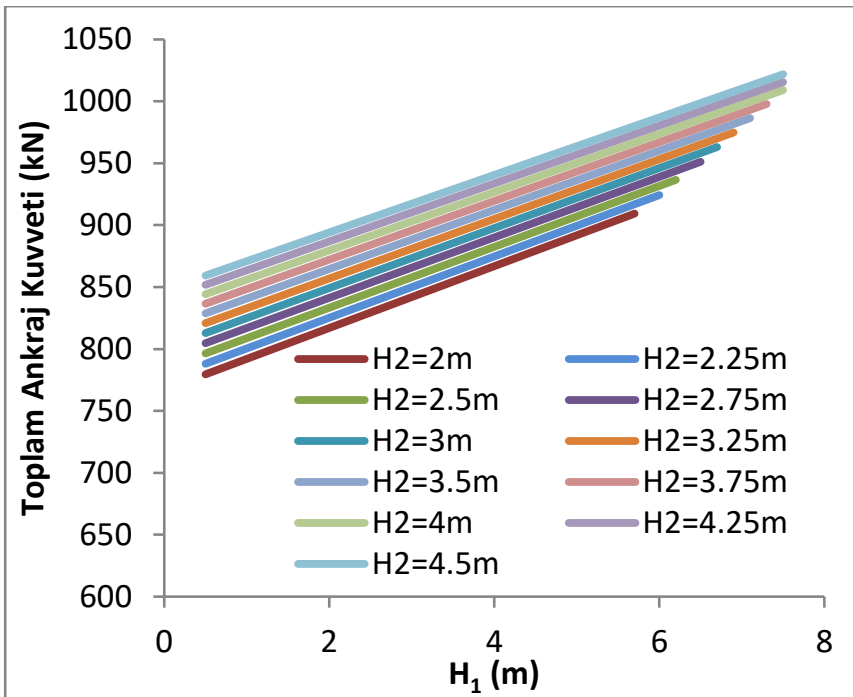

Şekil 8. $H=15 m$ ve $n=2$ olan palplanşta ankrajların düşey mesafelerinin toplam ankraj kuvveti ile ilişkisi

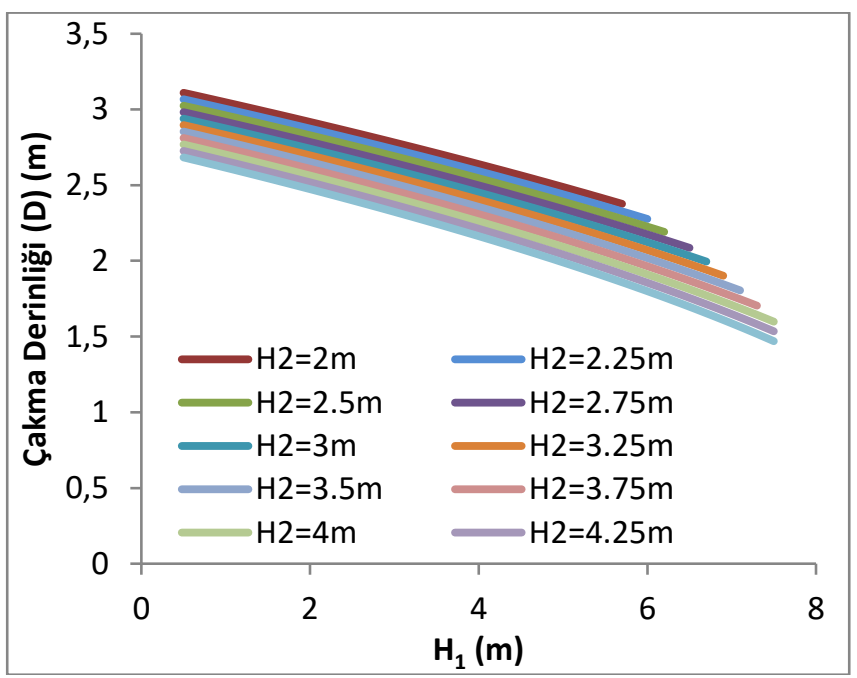

Şekil 9. $H=15 m$ ve $n=2$ olan palplanşta ankrajların düşey mesafelerinin palplanşın çakma derinliğine etkisi

Şekil 9'a bakıldığında, $\mathrm{H}_{1}$ ve $\mathrm{H}_{2}$ değerlerinin artması ile gerekli minimum palplanş çakma derinliklerinin azaldığı görülmektedir. Genel olarak $\mathrm{H}_{1}$ ve $\mathrm{H}_{2}$ değerinin artması ile Şekil 8'den de görüldüğü üzere ankraj kuvvetlerinin toplamı arttığı için, yatay denge denklemi kurularak Eşitlik (18)'den bulunan ve kazı altındaki zemin tarafından direnilmesi gereken reaksiyon kuvvetinin $(R)$ küçülmesinin bir sonucu olarak çakma derinliği de küçülmüştür.

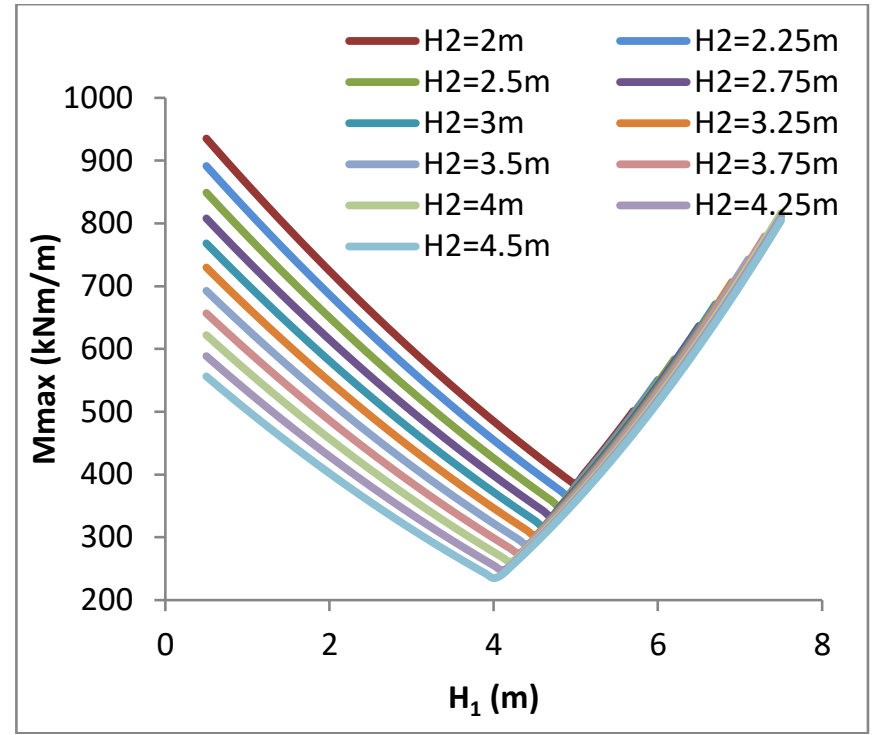

Şekil 10. $\mathrm{H}=15 \mathrm{~m}$ ve $\mathrm{n}=2$ olan palplanşta ankrajların düşey mesafelerinin palplanşa gelen maksimum eğilme momentine etkisi

Şekil 10'a bakıldığında, farklı $\mathrm{H}_{2}$ değerleri için oluşturulmuş her bir eğri için $\mathrm{H}_{1}$ 'in belirli bir değere kadar (yaklaşık olarak $4 \mathrm{~m}<\mathrm{H}_{1}<5 \mathrm{~m}$ ) artması ile duvara etki eden maksimum eğilme momentinin azaldığı fakat belirli bir değerden sonra $\left(\mathrm{H}_{1}>4 \sim 5 \mathrm{~m}\right)$ ise $\mathrm{H}_{1}$ değerinin artması ile maksimum eğilme momentinin arttığı görülmektedir. Ayrıca aynı $\mathrm{H}_{1}$ değerlerine karşılık farklı $\mathrm{H}_{2}$ değerleri için maksimum eğilme momentinin değişimi incelendiğinde, $\mathrm{H}_{2}$ değerinin artması ile duvara etki eden maksimum eğilme momentinin azaldığı görülmektedir. $\mathrm{H}_{1}>4 \sim 5 \mathrm{~m}$ olduğu durumda $\mathrm{H}_{1}$ değerinin artmasının bir sonucu olarak düşey ankraj takımı duvar tabanına çok yaklaşmakta ve bunun sonucu olarak en üst ankraj konumunda meydana gelen negatif eğilme momenti büyümektedir. Sonuç olarak belirli bir $\mathrm{H}_{1}$ değerinden sonra $\left(\mathrm{H}_{1}>4 \sim 5 \mathrm{~m}\right)$ maksimum momentler 1 . ankraj konumunda oluşmaya başlamakta ve artan $\mathrm{H}_{1}$ değerlerine karşılık olarak da bu maksimum momentler artmaktadır. Eşitlik (18)'e bakıldığında 1. ankraj konumunda oluşan bu momentin büyüklügünün $\mathrm{H}_{1}$ ve $\mathrm{p}$ değerlerine bağlı olduğu görülmektedir. $\mathrm{H}_{1}>4 \sim 5$ m olduğu durumda artan $\mathrm{H}_{1}$ değerlerine karşılık farklı $\mathrm{H}_{2}$ değerleri için maksimum eğilme momenti büyüklüklerinin birbirine yakın olmasının nedeni ise toprak basıncı zarfının maksimum basınç ordinatı olan p'nin büyüklüğünün $\mathrm{H}_{1}$ ve $\mathrm{H}_{2}$ 'nin artışına bağlı olarak az miktarda küçülmesidir. 


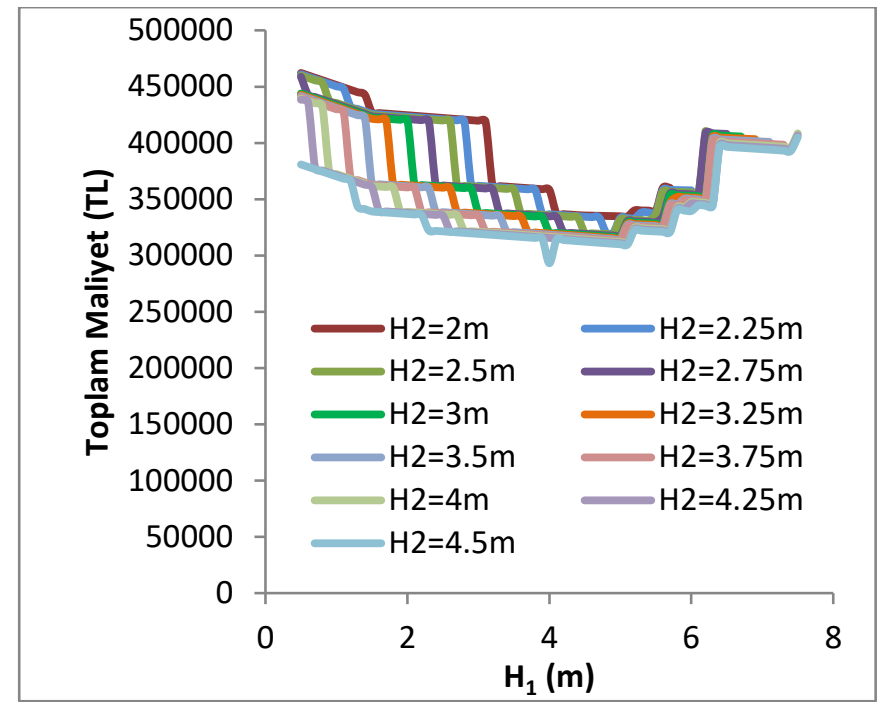

Şekil 11. $H=15 m$ ve $n=2$ olan palplanşta ankrajların düşey mesafelerinin iksa sisteminin toplam maliyetine etkisi

Şekil 11'den $\mathrm{H}_{2}$ ve $\mathrm{H}_{1}$ değerlerinin artması ile genel olarak iksa sisteminin toplam maliyetinin azaldığı görülmektedir. Buradaki her bir eğri incelendiğinde eğrilerde anı sıçramalar ve düşüşlerin olduğu görülmektedir. $\mathrm{H}_{1}$ değerinin artması ile $\mathrm{H}_{1}$ - Maliyet eğrilerindeki ani düşüşlerin nedeni, düşüşün yaşandığı iki nokta arasında, duvarda meydana gelen maksimum eğilme momentine bağlı olarak hesaplanan minimum kesit modülünü karşılayacak şekilde seçilen duvar kesitlerinde meydana gelen küçülmedir. Bununla birlikte yaklaşık olarak $\mathrm{H}_{1}>5 \mathrm{~m}$ olduğu durumda meydana gelen ani sıçramaların nedeni ise ani düşüşe neden olan sebebin tam tersi olarak duvar kesitinde meydana gelen büyüme sonucu palplanş duvarın birim maliyetinin artmasıdır. Öte yandan $\mathrm{H}_{2}=4,5 \mathrm{~m}$ ve $\mathrm{H}_{1}=4 \mathrm{~m}$ olduğu durumda, $\mathrm{H}_{1}$-Maliyet eğrisinde meydana gelen düşüşün nedeni de yine bu geometri durumunda duvarın kesit modülünün küçülmesi ile seçilen duvar kesitinde meydana gelen küçülme sonucu maliyetin düşmesidir.

Ankrajlar arasındaki yatay mesafenin ankraj kuvvetlerine ve iksa sisteminin toplam maliyetine etkisini gösteren grafikler Şekil 12 ve Şekil 13 'te verilmiştir.

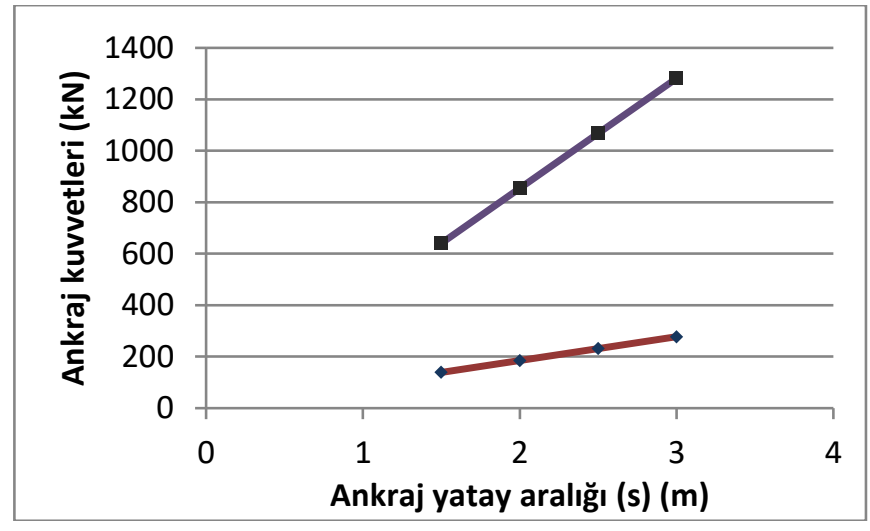

Şekil 12. $H=15 m$ ve $n=2$ olan palplanşta ankraj yatay aralığının ankraj kuvvetlerine etkisi

Burada, ankrajlar arasındaki yatay mesafenin artması ile daima ankraj kuvvetleri büyümektedir.

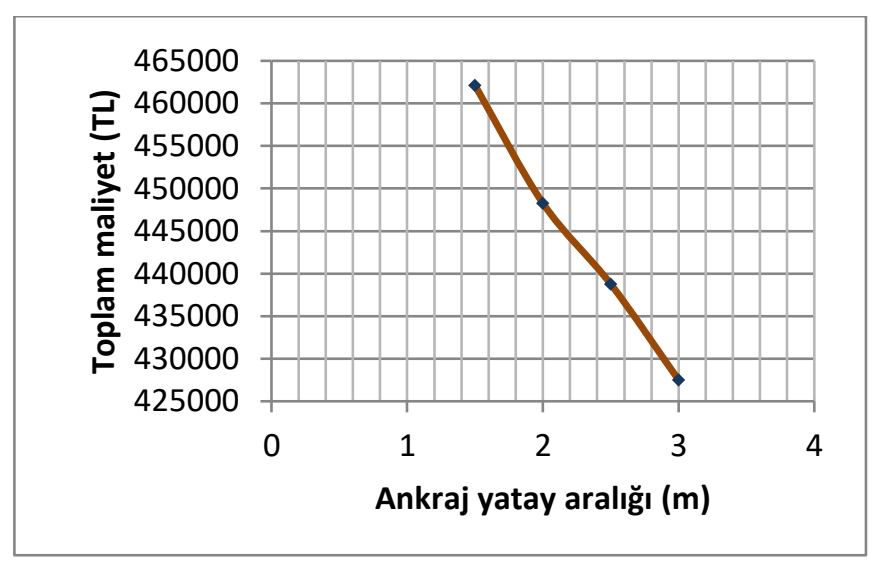

Şekil 13. $H=15 m$ ve $n=2$ olan palplanşta ankraj yatay aralığının iksa sisteminin toplam maliyetine etkisi

Şekil 13 'e bakıldığında yatay aralığın artması ile kullanılacak ankraj sayısı azaldığı için toplam maliyet genelde azalmaktadır. $15 \mathrm{~m}$ kazı derinliğine sahip 2 ankrajı palplanş sistemine ait sadece birkaç geometri durumunda, ankraj yatay aralığı $2.5 \mathrm{~m}$ olana kadar maliyet azalmış fakat $3 \mathrm{~m}$ olduğu zaman maliyet tekrar artmaya başlamıştır. 2.5 m'den büyük yatay aralık değerlerinin kullanılması ile ankraj kuvvetlerinin büyümesi sonucu ankrajlarda kullanılacak halat sayılarında ve de ankrajın kök bölgesi uzunluğunda artış meydana gelmekte ve bu artışın sistemin maliyeti üzerindeki arttırıcı etkisinin artan yatay aralık sonucu azalan ankraj sayısının maliyet üzerindeki azaltıcı etkisinden daha büyük olması bu durumu açıklamaktadır.

Ankrajın yatayla yaptığı açının ankraj kuvvetine ve de gerekli minimum ankraj gövde uzunluğuna etkisi Şekil 14 ve Şekil 15 'te gösterilmiştir. 


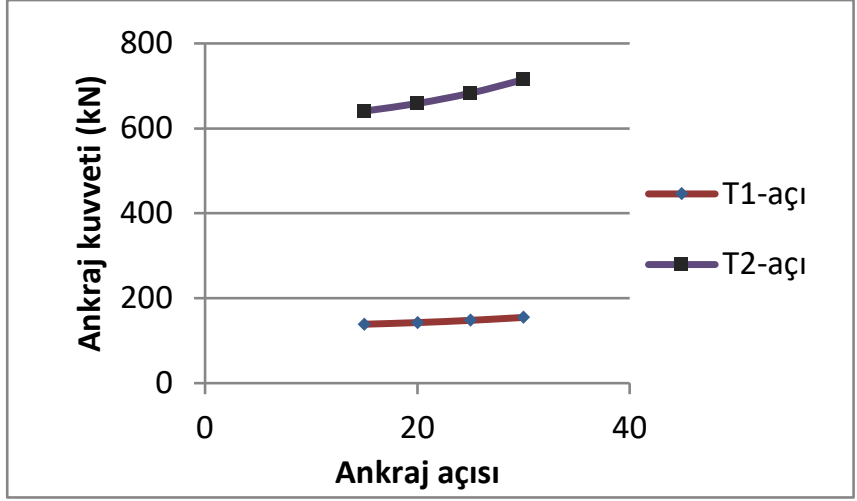

Şekil 14. $H=15 m$ ve $n=2$ olan palplanşta ankraj açısının ankraj kuvvetlerine etkisi

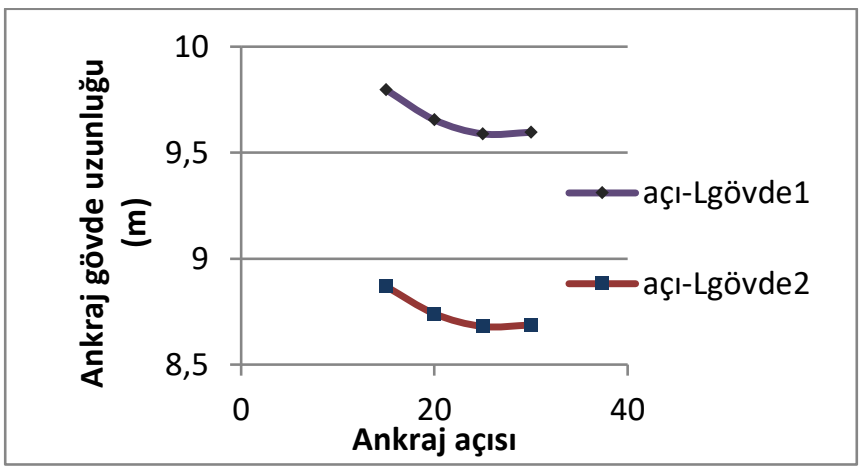

Şekil 15. $H=15 m$ ve $n=2$ olan palplanşta ankraj açısının gerekli minimum ankraj gövdesi uzunluğuna etkisi

Şekil 14'e bakıldığında, ankraj açısının artması ile ankraj kuvvetleri daima büyümektedir. Bunun bir sonucu olarak ankraj için gerekli minimum kök uzunlukları da büyümekte, bu durum maliyeti arttırmaktadır. Ayrıca artan ankraj kuvvetleri, ankraj için gerekli halat sayılarının belirlenmesinde kullanılan Tablo 1 'deki sınır kuvvet değerlerinden ait olduğu aralığın üst sınır kuvvetini aşarsa gerekli halat sayısı artacağından maliyet yükselecektir. Öte yandan ankraj açısının artması ile gerekli minimum gövde uzunluğu ise azalmaktadır (Şekil 15). Çünkü ankraj eğim açısının artması ile ilgili ankrajın kök bölgesinin aktif göçme düzleminin dışına çıkabilmesi için gerekli minimum gövde uzunluğu küçülmektedir. Ankraj gövde uzunluğunun küçülmesi ise maliyeti düşürmektedir. Sonuç olarak ankraj açısının artması ile meydana gelecek ankrajın kök uzunluğundaki ve de halat sayısındaki olası bir artış ile ankraj gövde uzunluğundaki azalışın büyüklükleri arasındaki fark, maliyet üzerindeki değişimi belirleyecektir.

$\mathrm{H}=15 \mathrm{~m}$ ve $\mathrm{n}=2$ olan palplanşta palplanş kesitinin toplam maliyet üzerine etkisini temsil eden grafik Şekil 16 'da gösterilmiştir.

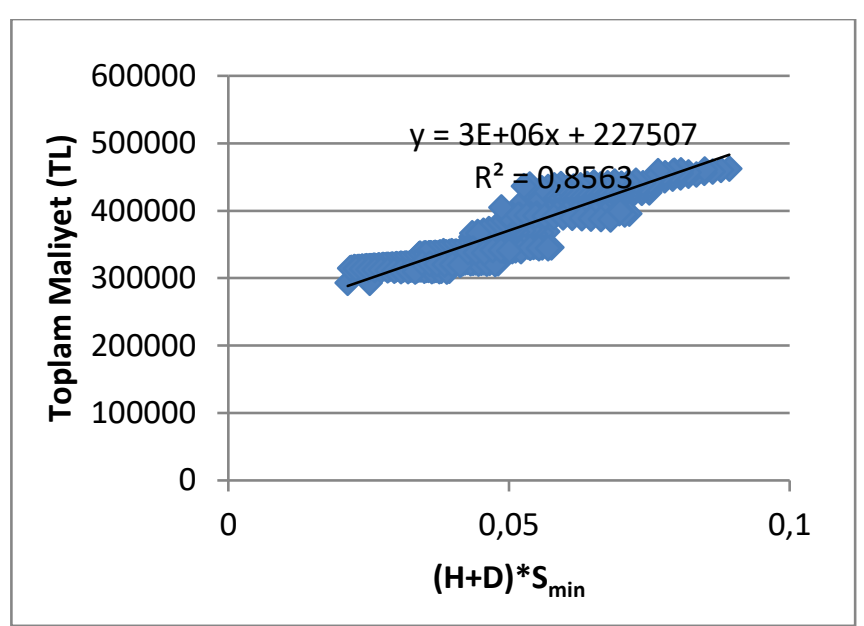

Şekil 16. $H=15 m$ ve $n=2$ olan palplanşta palplanş kesitinin iksa sisteminin toplam maliyetine etkisi

Das ve Das (2015)'in palplanş kesitinin optimize edilmesinin palplanş uzunluğu ve kesit modülünün minimize edilmesine bağlı olarak ifade edilebileceği görüşleri dikkate alınarak içerisinde palplanş uzunluğunu ve de kesit modülünü çarpan olarak barındıran apsis değerlerine karşılık toplam maliyet değerleri için grafik oluşturulmuştur (Şekil 16).

İki ankrajlı palplanş için yapılan hesaplamalar sonucunda farklı ankraj yatay aralıkları ve ankraj açılarına ait elde edilen optimum maliyetler Tablo 6'da görülmektedir.

Tablo 6. $\mathrm{H}=15 \mathrm{~m}$ ve $\mathrm{n}=2$ olan palplanşta optimum maliyetler

\begin{tabular}{|c|c|c|}
\hline \multicolumn{3}{|c|}{$\mathrm{H}=15 \mathrm{~m}$ ve $\mathrm{n}=2$} \\
\hline & $\begin{array}{l}\text { Ankraj Açısı } \\
\left({ }^{\circ}\right)\end{array}$ & $\begin{array}{l}\text { Minimum Maliyet } \\
(\mathrm{TL})\end{array}$ \\
\hline \multirow{4}{*}{$\mathrm{s}=3 \mathrm{~m}$} & 30 & 276394.75 \\
\hline & 25 & 275472.42 \\
\hline & 20 & 274914.86 \\
\hline & 15 & 274695.08 \\
\hline \multirow{4}{*}{$\mathrm{s}=2,5 \mathrm{~m}$} & 30 & 275595.35 \\
\hline & 25 & 274769.68 \\
\hline & 20 & 274296.40 \\
\hline & 15 & 274152.37 \\
\hline \multirow{4}{*}{$\mathrm{s}=2 \mathrm{~m}$} & 30 & 283829.71 \\
\hline & 25 & 279939.80 \\
\hline & 20 & 279766.10 \\
\hline & 15 & 279886.71 \\
\hline \multirow{4}{*}{$\mathrm{s}=1,5 \mathrm{~m}$} & 30 & 292359.06 \\
\hline & 25 & 292333.10 \\
\hline & 20 & 292567.92 \\
\hline & 15 & 293072.61 \\
\hline
\end{tabular}


Analizler incelendiğinde optimum maliyetler daima, bu çalışma kapsamında kullanılan en düşük palplanş kesit türü olan LARSSEN 22'de oluşmuştur ve de $15 \mathrm{~m}$ kazı derinliğine sahip 2 ankrajlı palplanş sistemine ait birkaç geometri hariç diğer tüm durumlarda en düşük maliyetler, ankraj yatay aralığının 3 m olduğu durumda gözlenmiştir.

Ayrıca ankraj açısının artması ile ankraj kuvvetleri büyümüş ve bu büyüme sonucu gerekli minimum kök uzunluklarında meydana gelen artış sonucu maliyet artmıştır. Ankraj kuvvetinin büyümesi sonucu gerekli halat sayısı da artarsa bu durum da ilave maliyet doğuracaktır. Buna karşılık ankraj açısının artması ile ankraj için gerekli minimum gövde uzunluklarının küçülmesi durumu maliyet üzerinde azaltıcı etkiye sahiptir.

Buradan yola çıkarak genel olarak $15 \mathrm{~m}$ kazı içindeki palplanşlar için ankraj yatay aralığının 2.5 m'den ve ankraj açısının $15^{0}$ 'den daha büyük alınmasının palplanş maliyetini optimum maliyetten uzaklaştırdığı sonucuna varılabilir.

Analizler sonucunda elde edilen ortalama ankraj, palplanş ve kuşak maliyetlerinin ortalama toplam maliyet içerisindeki paylarını gösteren pasta grafik aşağıda sunulmuştur.

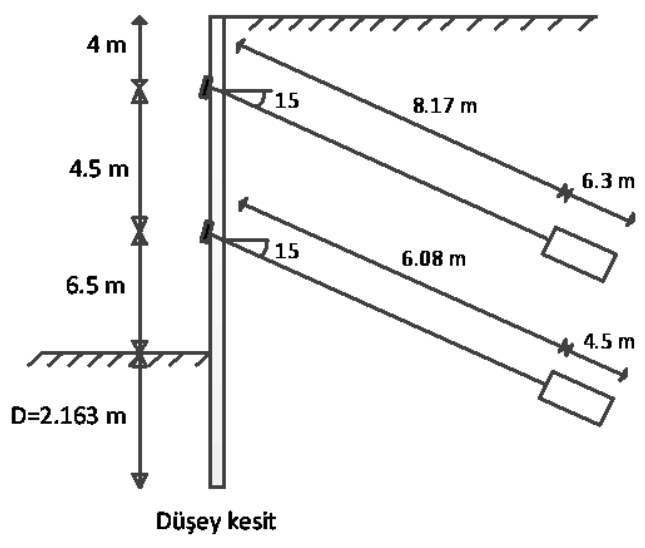

\section{$H=15 m, n=2$}

- Ort Ankraj maliyeti Ort Palplanş Maliyeti

Kuşak maliyeti

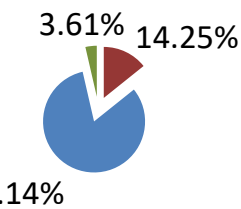

Şekil 17. $H=15 m$ ve $n=2$ olan palplanşın analizlerinden elde edilen ortalama ankraj maliyeti, ortalama palplanş maliyeti ve kuşak maliyetinin karşılaştırılması

Şekil 17 incelendiğinde; 15 m kazı derinliğine sahip 2 ankrajlı palplanş sistemi için yapılan analizler sonucunda ortalama toplam maliyetin yaklaşık olarak \%3.61'ini kuşak maliyetinin, \%14.25'ini ortalama ankraj maliyetinin, \%82.14'ünü ise ortalama palplanş maliyetinin oluşturduğu görülmektedir. Pasta grafiklerinin tümü incelendiğinde, çok ankrajlı bir palplanş sisteminin ortalama toplam maliyeti üzerinde palplanş maliyetinin en büyük etkiye sahip olduğu sonucu çıkarılabilir. Ayrıca palplanş, ankraj ve kuşak maliyetlerinin toplam maliyet içerisindeki payları göz önüne alındığında, büyükten küçüğe pay sıralamasının; palplanş maliyeti>ankraj maliyeti>kuşak maliyeti olduğu görülmektedir. Bu sebepten ötürü en düşük maliyetlerin genelde en düşük palplanş kesiti kullanıldığında elde edildiği gözlemlenmiştir.

Sonuç olarak $15 \mathrm{~m}$ kazı derinliğine sahip 2 ankrajlı palplanş sisteminin minimum maliyete sahip geometrisine ait kesit özellikleri Şekil 18 ve bu kesitin analizleri sonucunda elde edilen kuvvetler ve maliyetler ise Tablo 7'de verilmiştir.

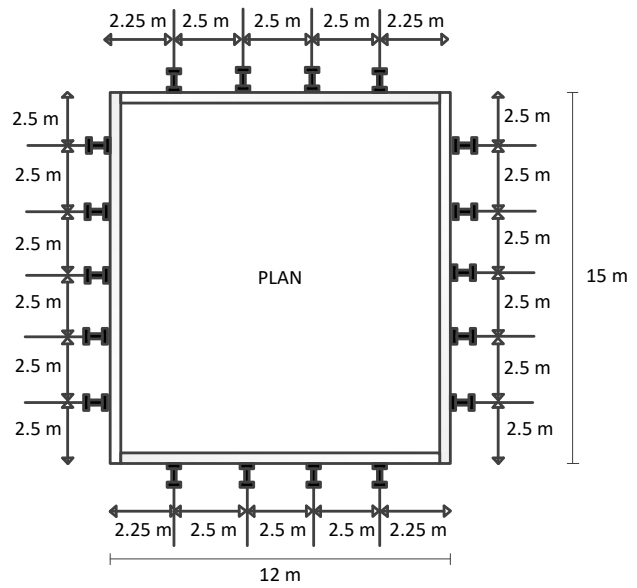

Şekil 18. $H=15$ m ve $n=2$ olan palplanş sistemi için minimum maliyete sahip geometrinin düşey kesiti ve planı 
Tablo 7. $\mathrm{H}=15 \mathrm{~m}$ ve $\mathrm{n}=2$ olan ve optimum maliyete sahip palplanş sistemine ait çıktılar

\begin{tabular}{|l|l|}
\hline 1. ankraj kuvveti $\left(\mathrm{T}_{1}\right)(\mathrm{kN})$ & 914.888 \\
\hline 2. ankraj kuvveti $\left(\mathrm{T}_{2}\right)(\mathrm{kN})$ & 652.768 \\
\hline 1. ankrajdaki halat sayısı & 4 \\
\hline 2. ankrajdaki halat sayısı & 3 \\
\hline $\begin{array}{l}\text { Maksimum eğilme momenti }\left(\mathrm{M}_{\max }\right) \\
(\mathrm{kNm} / \mathrm{m})\end{array}$ & 235.051 \\
\hline Minimum kesit modülü $\left(\mathrm{S}_{\min }\right)\left(\mathrm{cm}^{3} / \mathrm{m}\right)$ & 1239 \\
\hline Kesit türü & LARSSEN \\
\hline Çakma Derinliği $(\mathrm{D})(\mathrm{m})$ & 22 \\
\hline Palplanşın maliyeti $(\mathrm{TL})$ & 2.163 \\
\hline Ankrajların toplam maliyeti $(\mathrm{TL})$ & 223686.57 \\
\hline Kuşak maliyeti $(\mathrm{TL})$ & 37832.75 \\
\hline Toplam maliyet $(\mathrm{TL})$ & 12633.06 \\
\hline
\end{tabular}

\section{TARTIŞMA VE SONUÇLAR}

Genel olarak analizler incelendiğinde, ankraj açısının artması ile ankraj kuvvetleri artmaktadır. Buna bağlı olarak eğer ankrajda kullanılması gereken halat sayısı artarsa ankraj birim maliyeti de yükselecektir. Öte taraftan, ankraj açısının artması ile ankraj için gerekli minimum gövde uzunluğu azaldığı için, bu durum ise maliyet üzerinde düşürücü etkiye sahip olmaktadır. Yine ankraj açısının artması ile ankraj kuvvetlerinin büyümesinin bir sonucu olarak yeterli sıyrılma direncine sahip olması istenen kök bölgesinin minimum uzunluğu da artmaktadır. Bu durum da maliyet üzerinde arttırıcı bir etkiye sahip olmaktadır. Tüm analizler incelendiğinde optimum maliyetlerin genellikle ankraj açısının $15^{\circ}$ olduğu durumda oluştuğu görülmektedir.

Ankrajlar arası yatay aralığın artması ile ankraj kuvvetleri büyümektedir. Ankraj kuvvetlerindeki bu büyüme sonucunda her bir ankraj için gerekli minimum halat sayısı artarsa maliyet artacaktır. Ayrıca ankraj kuvvetlerindeki bu artış sonucunda sıyrılmaya karşı güvenli olması istenen kök bölgesi için gerekli minimum uzunluk da arttığı için maliyetler artmaktadır. Buna karşılık ankrajlar arası yatay mesafenin artması ile kazı alanı içerisinde kullanılacak ankraj sayısı azalacağı için maliyet azalmaktadır. Yatay aralığın artması sonucunda ankraj sayısındaki azalmanın maliyet üzerindeki azaltıcı etkisinin, ankraj kuvvetindeki artışın maliyet üzerindeki arttırıcı etkisine daha baskın olması nedeniyle, ankraj yatay aralığının artması ile maliyetler genel olarak azalmıştır. Fakat bu çalışma kapsamında palplanş sisteminin geometrisine bağlı olarak optimum maliyet, ankraj yatay aralığının 2.5 $\mathrm{m}$ olduğu durumda meydana gelmiştir.
Ankrajların düşey mesafelerinin artması ile belirli bir düşey aralık değerine kadar genel olarak maliyetler azalmaktadır. Fakat belirli bir düşey aralık değerinden sonra ankraj takımının kazı tabanına fazlaca yaklaşması ile maksimum eğilme momentleri 1 . ankraj konumunda meydana gelmekte ve ankrajların düşey mesafelerinin artması ile bu moment artmaktadır. Buna istinaden, artan eğilme momentlerine karşılık mevcut palplanş kesiti yetersiz kalırsa palplanş kesitinin büyütülmesi gerekliliği ortaya çıktığı için maliyetler tekrar artacaktır. Ankrajlar arası düşey mesafenin artması ile aynı zamanda palplanş için gerekli minimum çakma derinliği de azalmaktadır.

Analizlerden elde edilen maliyetler incelendiğinde maliyetlerin büyük çoğunluğunu palplanş maliyeti oluşturduğu için en düşük maliyetler, en küçük kesite sahip palplanş sistemlerinde meydana gelmiştir. Aynı kesit modülüne sahip palplanşların maliyetleri arasındaki farklılığı ise ankraj düşey aralıklarına bağlı olarak değişen çakma derinlikleri ve ankraj kuvvetleri belirlemektedir.

Yapılan analizler neticesinde elde edilen kesitlerin büyük çoğunluğunun LARSSEN 23 ve üzerinde çıktığı gözlemlenmektedir. Fakat analizler içerisinde sadece 16 adet geometriye ait palplanş kesiti LARSSEN 22 çıkmıştır ve bu 16 geometri içerisinde optimum maliyete sahip olan kesiti belirleyen ankraj maliyeti olmuştur.

\section{TEŞEKKÜR}

$\mathrm{Bu}$ çalışma Süleyman Demirel Üniversitesi Bilimsel Araştırma Projeleri Koordinasyon Birimi tarafından FYL2019-6980 nolu proje kapsamında desteklenmiştir.

\section{KAYNAKLAR}

Amer, H.A.R. (2013). Effect of Wall Penetration Depth on the Behaviour of Sheet Pile Walls. University of Dayton, M.Sc. Thesis. 145p, Dayton.

Arslan, B., Öztoprak, S. (2005). Derin Kazılarda Çok Sıra Ankrajlı İksa Sistemleri İle Ankaster Fore Kazık İksa Sistemlerinin Tasarımı ve Maliyet Karşılaştırması. II. Mühendislik Bilimleri Genç Araştırmacılar Kongresi, 17-19 Kasım, İstanbul, 429-440.

Bhanuchitra, M., Prusty, S.B. (2010). Optimal Design of the Shoring System: A Parametric Study. Indian Geotechnical Conference, 16-18 Aralık, Mumbai, 223-227.

Bilgin, Ö. (2012). Lateral Earth Pressure Coefficients for Anchored Sheet Pile Walls. International Journal of Geomechanics, 12(5), 584-595.

BS 8081, (1989). British Standard Code of Practice for Ground Anchorages. BSI, London.

Das, M.R., Das, S.K. (2015). Optimal Design of Sheet Pile Wall Embedded in Clay. The Institution of Engineers, 96(3), 249-258. 
Erdem, K., Karabacak, E., Yasavul, N., Sivrikaya, O. (2015). Derin Kazı Modellemesi ve Maliyet Hesabı. 6. Geoteknik Sempozyumu, 26-27 Kasım 2015, Adana, 944-955.

Fenerci, E. (2010). Palplanş Perdeli Derin Kazı Destek Sistemlerinde Zemin Kesiti ve Tasarım Yönteminin Etkisi. Sakarya Üniversitesi, Fen Bilimleri Enstitüsü, Yüksek Lisans Tezi, 106, Sakarya.

FHWA-IF-99-015, (1999). Geotechnical Engineering Circular No 7 Ground Anchors and Anchored Systems. FHWA, Washington.

Lopez, S., Sanhueza, C., Gandia, G. (2017). Anchored Piles Deep Excavations: A Case Study. 16th World Conference on Earthquake, 9-13 January, Santiago Chile, 1-11.
Mahdi, İ.M., Ebid, A.M. (2015). Optimum Penetration Depth of Cantilever Sheet Pile Walls in Dry Granular Soil Based on Reliability Analysis Concept And Its Impact on the Shoring System Cost. International Journal of Application or Innovation in Engineering \& Management, 4(5), 11-21.

NCHRP Report 611, (2008). Seismic Analysis and Design of Retaining Walls, Buried Structures, Slopes and Embankments. NCHRP, Washington.

Örnek, M., Laman, M., Yıldız, A, Demir, A., Tekinsoy, M.A. (2007). Ankrajı İksa Sistemlerinin Sayısal Analizi. 2. Geoteknik Sempozyumu, 22-23 Kasım, Adana, 216-229.

Plaxis 3D Foundation Tutorial Manual Version 2, (2007).

Terzaghi, K. Peck, R.B. (1967). Soil Mechanics in Engineeering Practice, John Wiley and Sons, New York. 